\title{
مسألة تزاحم الأحكام في تقييم الشخصيات لدى ابن تيمية
}

\section{بليل عبد الكريم}

$$
\begin{aligned}
& \text { الملخص }
\end{aligned}
$$

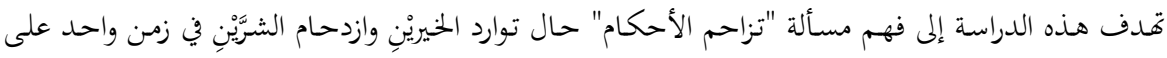

$$
\begin{aligned}
& \text { معين واحد. وهي من مسائل الفقه النادرة التي، امتاز بها الشرع الإسلامي، فأكسبته مرونة وصلابة في النظر إلى النوازل } \\
& \text { المكانية والزمانية في الأفراد والجماعات. وتئ. } \\
& \text { وقليل من الباحثين من سبر أغوار هذا الموضوع، لأنه صعب على غير أولي النهى من مثل ابن تيمية، الذي } \\
& \text { أعمل قاعدة التزاحم في العمليات والعلميات، وأعمل القاعدة في تقييم الأشخاص والعلوم. ومع أن دفاع ابن تيمية }
\end{aligned}
$$

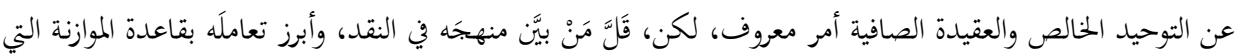

$$
\begin{aligned}
& \text { يقتضيها تزاحم الأحكام في نقد الفرد المُعيَّن، أو الجماعة المُعيَّنة. } \\
& \text { الكلمات المفتاحية: تزاحم الأحكام، التعارض، النقد، الموازنة. }
\end{aligned}
$$

\section{Rivalry of Judgments in the the Evaluation of individuals as perceived by Ibn Taymiyah}

\section{Abstract}

This study aims to understand the issue of judgments rivalry when two goods and two evils come on one issue at the same time. It is a unique issue, which has characterized Islamic law, and gave it flexibility and rigor in looking at the emerging issues in time and space, whether regarding individuals or groups.

Few people have studied this issue, as it is a difficult one expect for those thinkers like Ibn Taymiyyah who applied the rule of rivalry in the academic and theoretical aspects, and also in evaluating individuals and disciplines. Although his defense of straight tawhid and pure cread is well known, but very few have illustrated his methodology of criticism, and uncover his approach in dealing with the balance needed to settle the rivalry of judgments, regarding a certain individual or certain group.

Keywords: Rivalry of judgments, Opposing ideas, Criticism, Balance.

$$
\begin{aligned}
& \text { • دكتوراه في العقيدة ومقارنة الأديان؛ تخصص فلسفة إسلامية، جامعة الأمير عبد القادر للعلوم الإسامية بقسنطينة }
\end{aligned}
$$

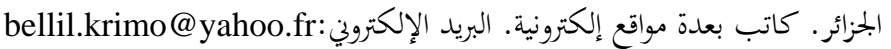

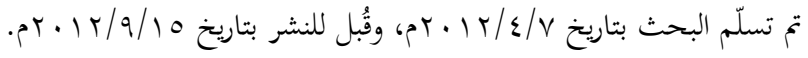


مقدمة:

تتنـاول هـذه الدراسـة جزئيسة مـن قضـية تشـغل الـرأي العـامّ للـدعاة وطلبـة العلـم والمفكّرين؛ هي تصنيف العلماء والدعاة والفضلاء، ونقد المشاريع الإصلاحية والأفكار

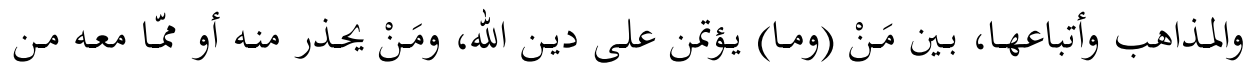
أفكار.

ومَنْ حوى خبراً من أيام الله بعد ظهور الاختلاف بين المسلمين، يدري دواعي بروز

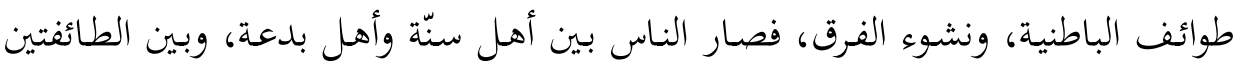

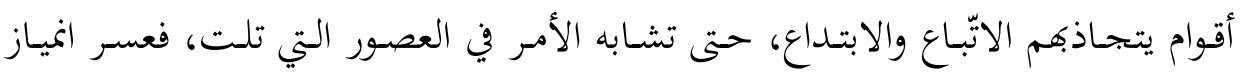

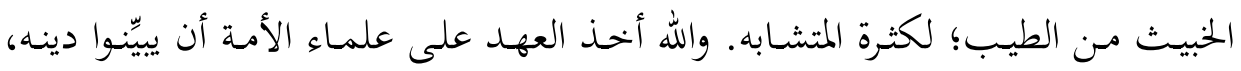

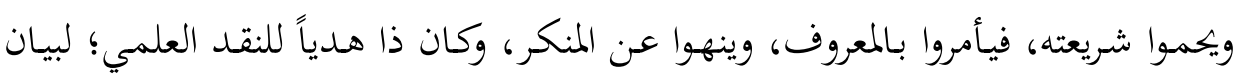

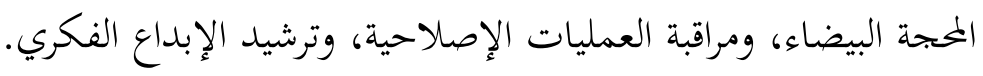

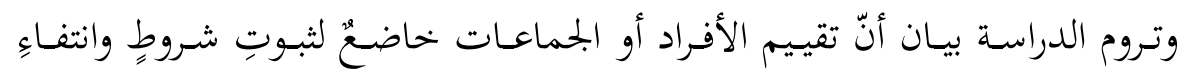

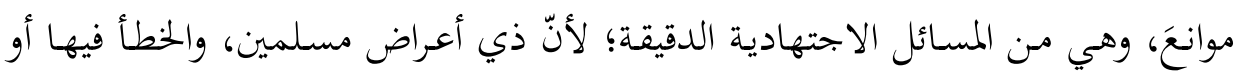
الغلوّ يؤدي إلى تشتيت الصف، وتهوين العزائم، وإضعافٍ لجهود الإصلاح. وأيامنا هذه كثر فيها مُصابنا، وتكاثر الأكلة من علينا، حرباً على مقوّماتنا وهويتنا

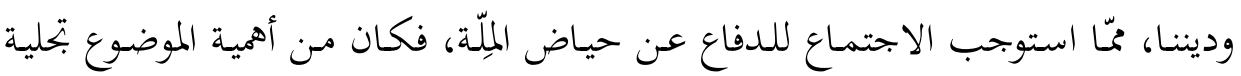

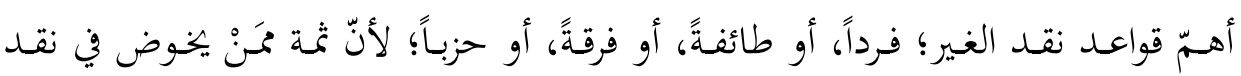

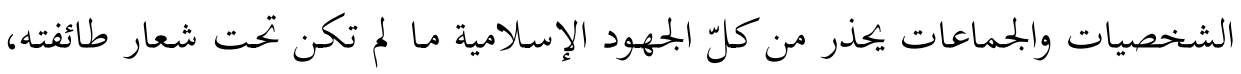

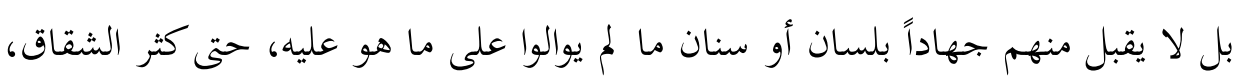
وتفشّى تعطيل المشاريع الإسلامية من الإسلاميين أنفسهم.

وطبيعة الدراسة تدور حول بيان أنّ المِلّة الإسلامية شريعة مقاصدية، تخدم الصالح

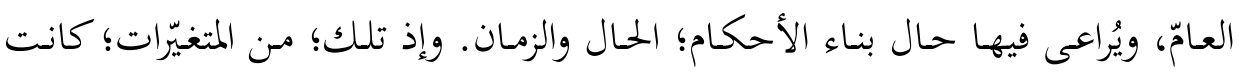

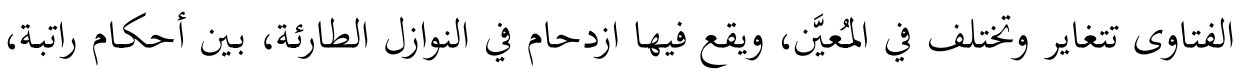




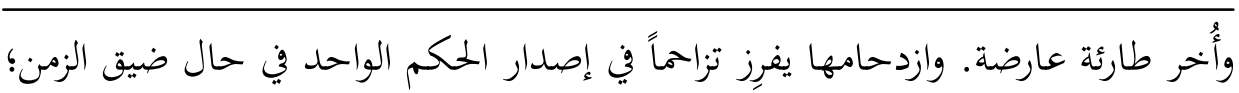

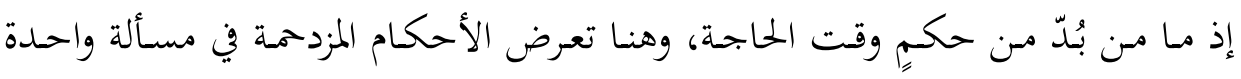

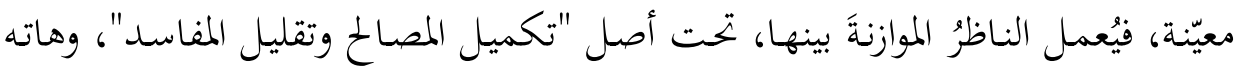

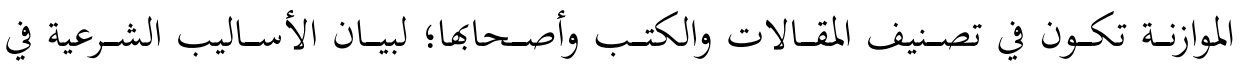
التعامل معهم.

\section{أولاً: مفهوم تزاحم الأحكام}

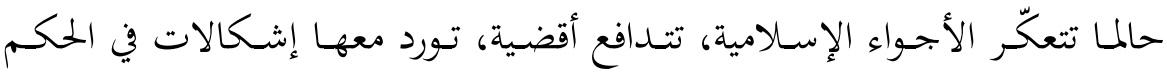

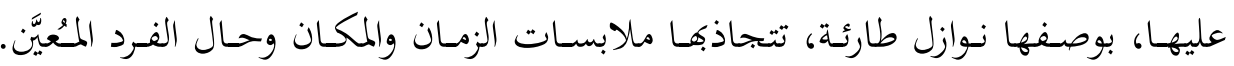

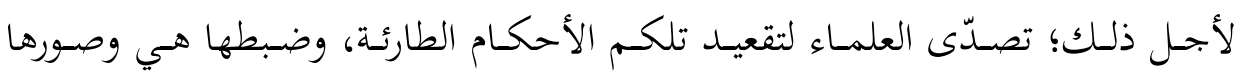

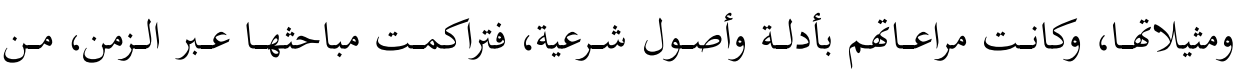

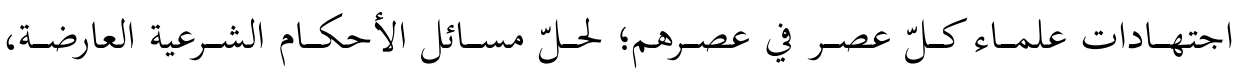
والتوسّط فيها، بين طريَ الإغفال المهِلك، والشدّة المفرِطة. وبيان قاعدة "تزاحم الأحكام" يتطلّب إلماماً بالنصوص، ودقّة في استيعاب معانيها،

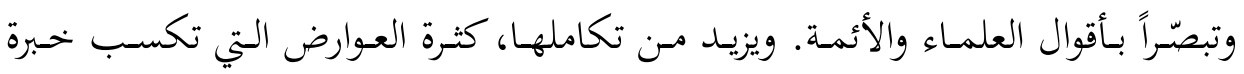
وملكة في التنظير والتقعيد.

ومفهوم "تزاحم الأحكام" يتببيَّن مـن خهلال استيعاب مقاصد الشـرع المنتزل، وفي

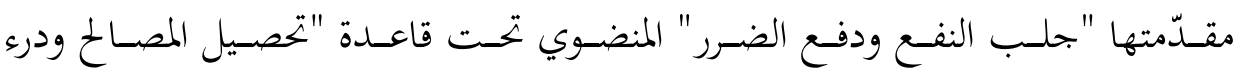

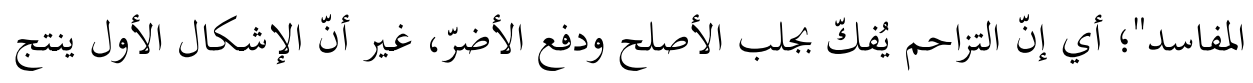

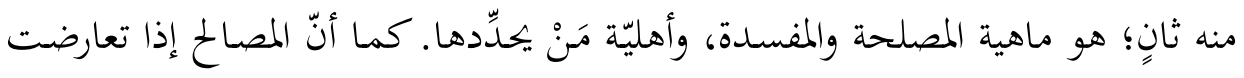

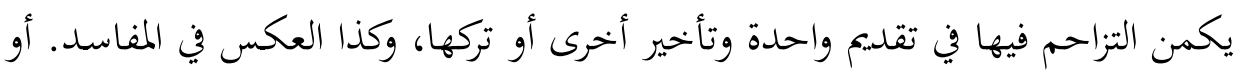

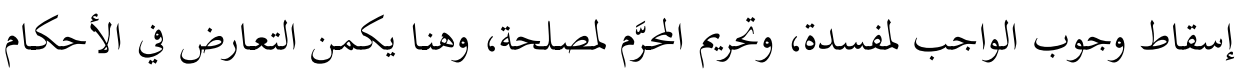

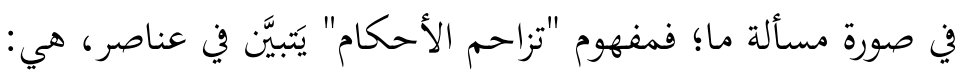
- - تقديم المصلحة على المفسدة. 
- معرفة تفاوت مراتب النفع والضرر.

- مراية المسائل التي قد تتعارض فيها الأحكام.

\section{I . تقرير قاعدة تحصيل المصالح ودرء المفاسد:}

مقاصد التشريع هي تحصيل الخير، فالدين نزل لخدمة الإنسان، وصلاح بني آدم في

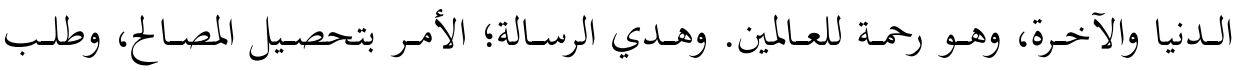

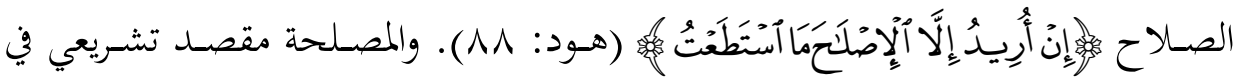
أفعال الإنسان، يقدّر قدرها المنصوص عليه في الشرع، "والأدلاء على تقدير المصلحة في مثل ذلك هم علماء المسلمين." ' '

وأصـل تزاحم الأحكام الشرعية أنّ "الشـرائع جـاءت بتحصيل المصـالح وتكميلها، وتعطيل المفاسد وتقليلها. فهي تأمر بما تترجح مصلحته، وإن كان فيه مفسدة مرجوحة؛ كالجهاد. وتنهى عما ترجحت مفسدته، وإن كان فيه مصلحة مرجوحة؛ كتناول المحرَّمات

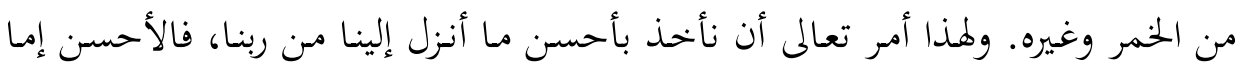

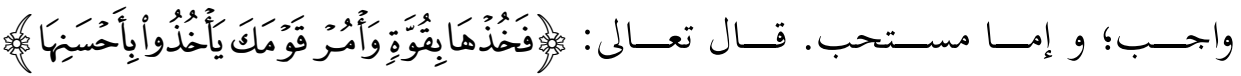

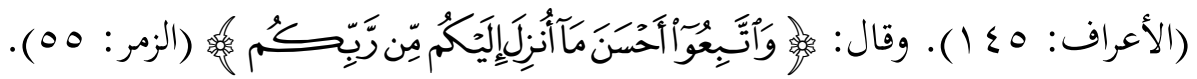
فأمر باتِّاع الأحسن والأخذ به.... ونظائر هذا كثيرة؛ مما يذكر فيه أن المأمور به خير

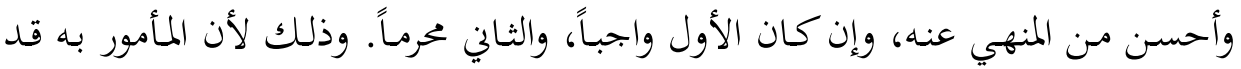
يشتمل على مفسدة مرجوحة، والمنهي عنه قد يشتمل على مصلحة مرجوحة، فيكون

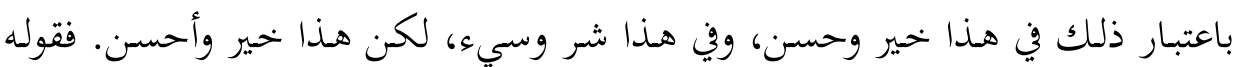

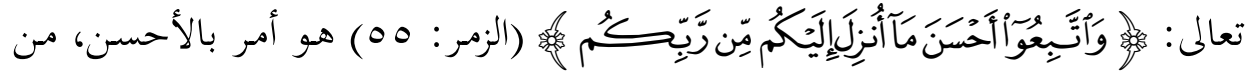
فعل المأمور، أو ترك المخور. وهو يتناول الأمر بالواجب والمستحب، فيإن كليهما أحسن

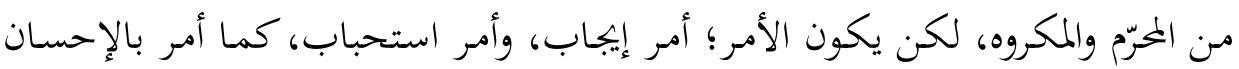
' احميـدان، إبـراهيم بـن صـالح. أسـلوب المنـاظرة في دعـوة النصـارى إلـى الإسـلام، الريـاض: دار الإمـام،

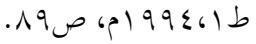




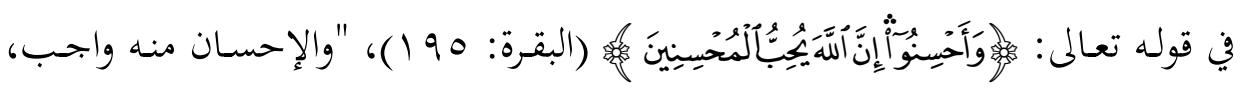

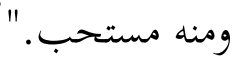

فالشرع جاء لتحصيل مصلحة خير الخيريْيْ إذا تواردا، وتعطيل مفسدة أشرّ الشرّيّنِ

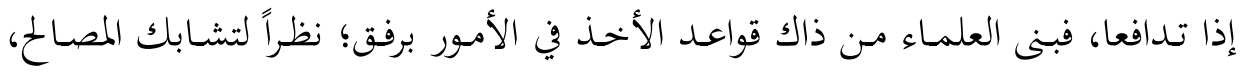

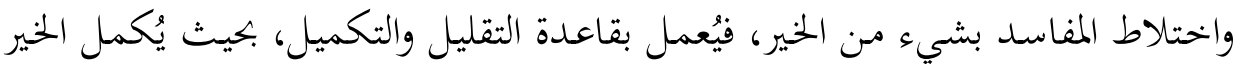

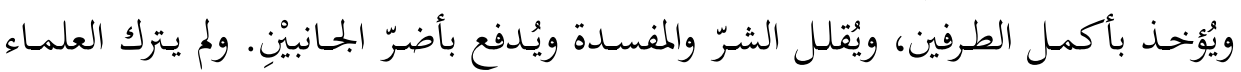

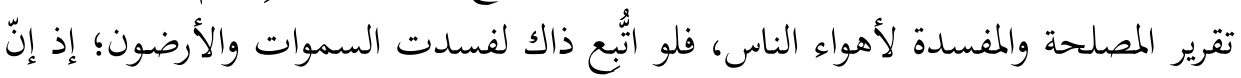
أهواءهم متضادة ومتنافرة.

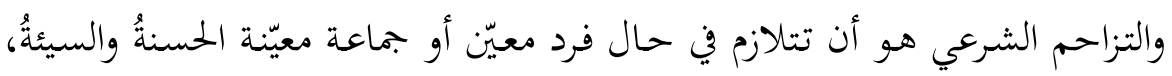

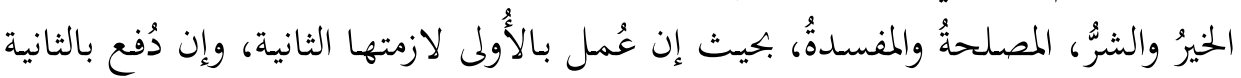

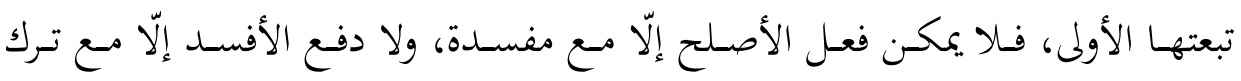

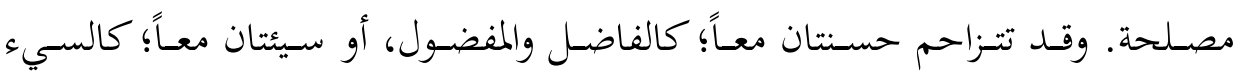

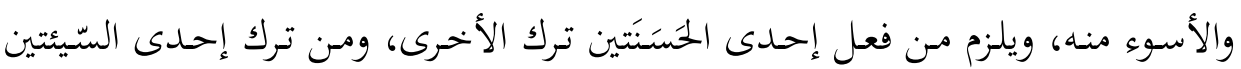

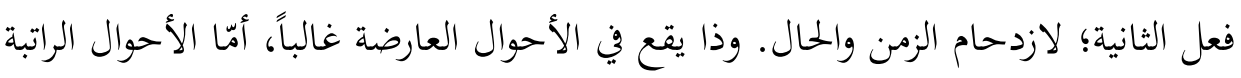

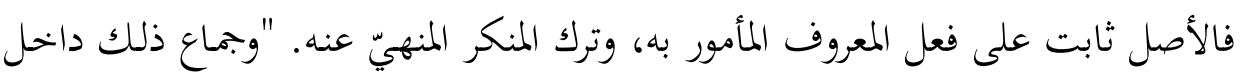

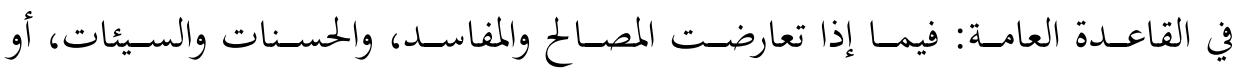

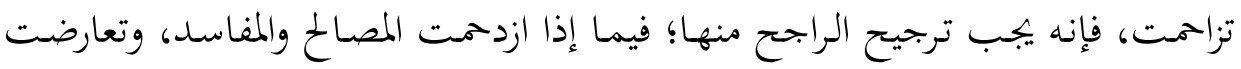

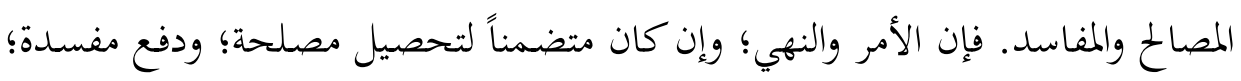

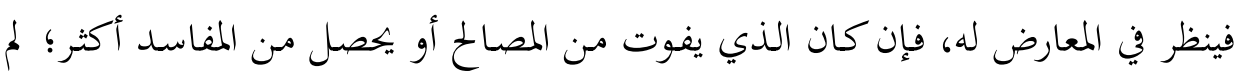

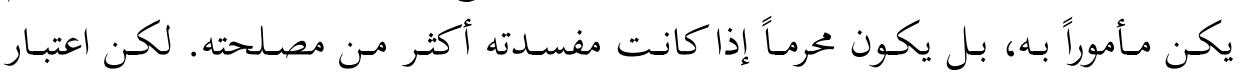

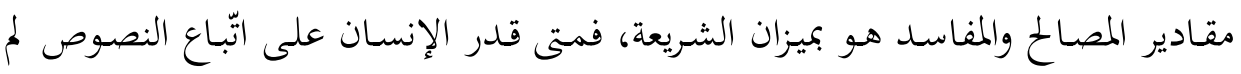

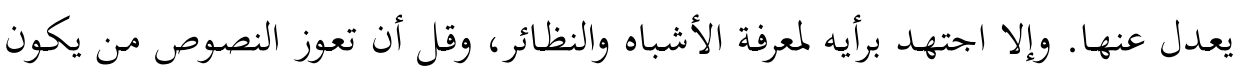

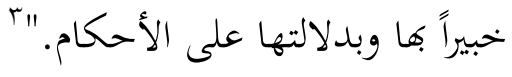

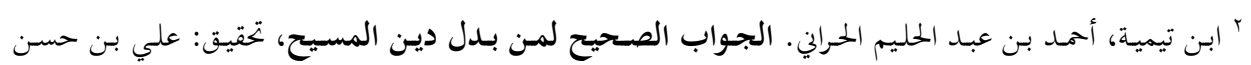

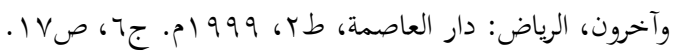

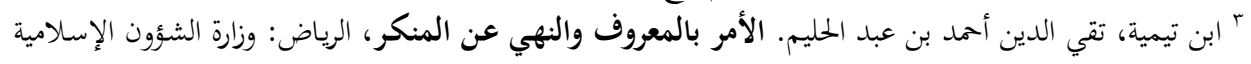

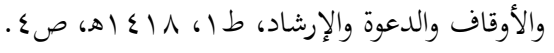


وبنـاءً على ذلك؛ قد يجتمع في المُعيَّن معروفُ ومنكرُ، حيـث لا سبيل لفصلهما؛

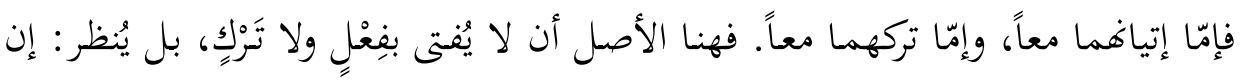

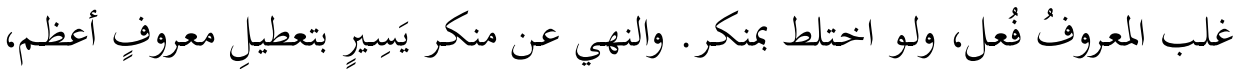

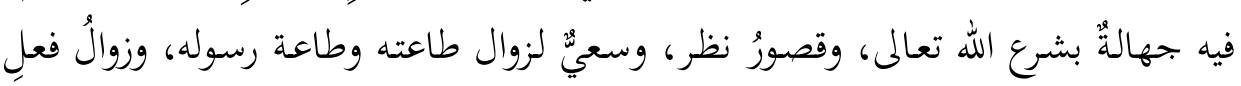

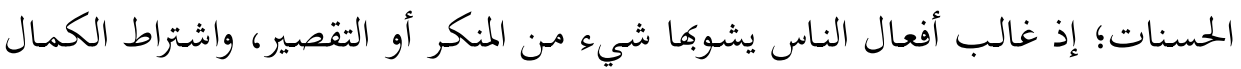
في قبول الأعمال فيه سعي لزوالها. وإن كان المنكر أغلب فهي عنه، ولم يُلتفت إلى المعروف الذي به لقّلّه، وإن تكافأ

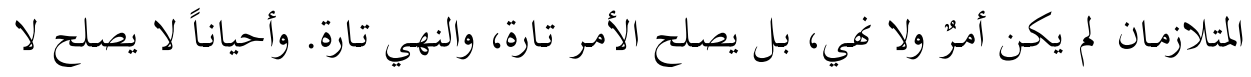

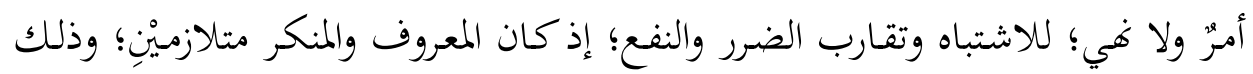

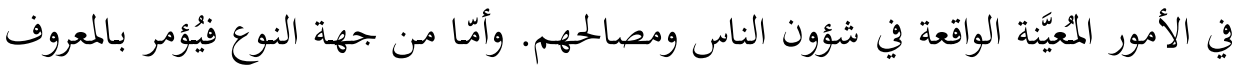
مطلقاً، ويُنهى عن المنكر مطلقاً. ومراتب المقاصد تُباين بين الوجوب بالأهمية، فيُقدّم وجوب حفظ النفس على غيره،

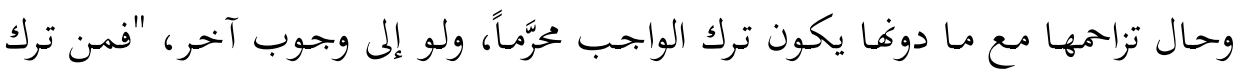

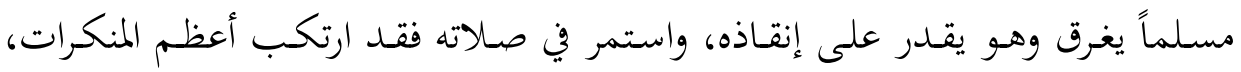
وترك أهم المعروفات، فلا هو عمل بالأدلة الواردة في الأمر بالمعروف، والنهي عن المنكر، وهرك،

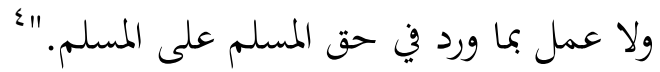

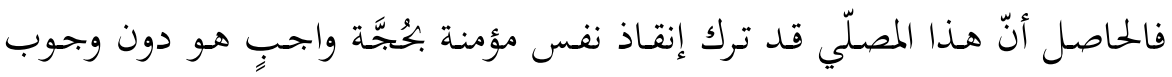

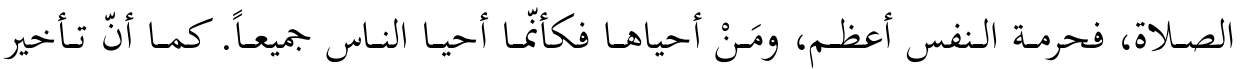

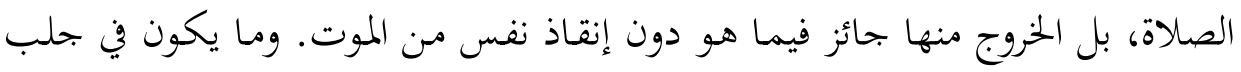

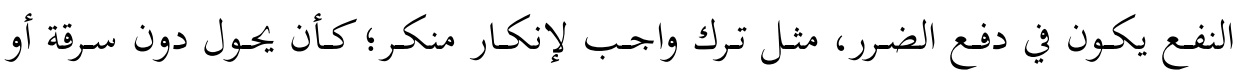

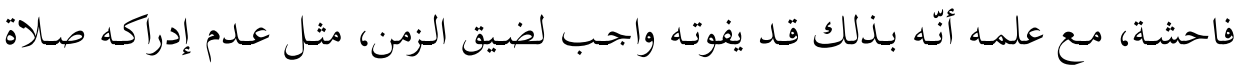

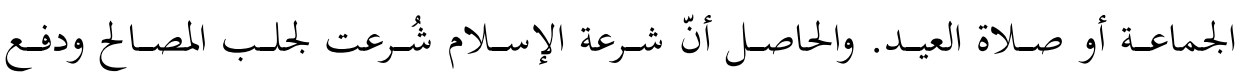
المفاسد، والموازنة بين المصالح والمفاسد، وتقديم الأهمّ منها على ما هو دونه.

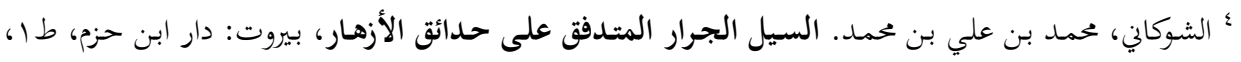




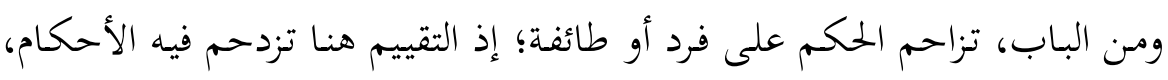

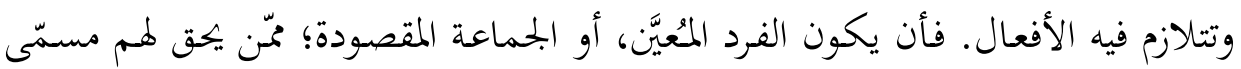

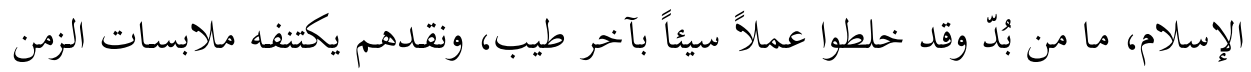

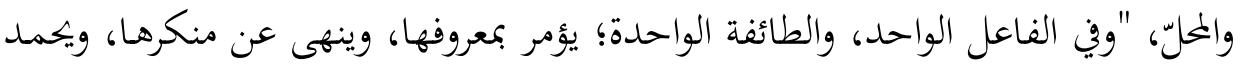

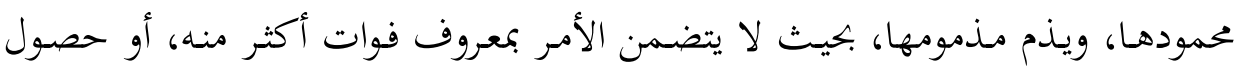

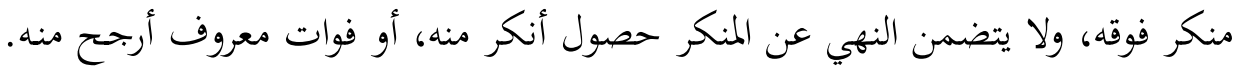

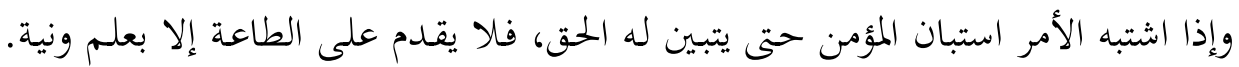

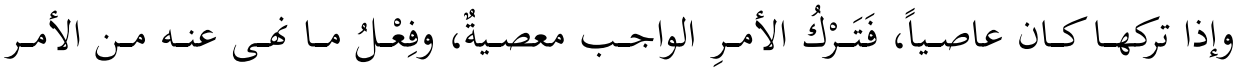

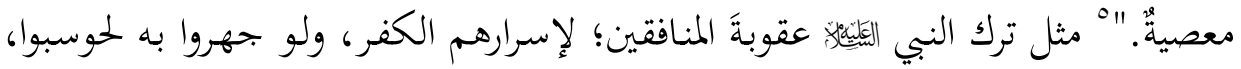

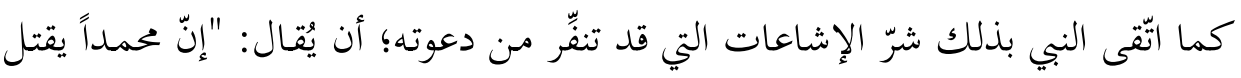

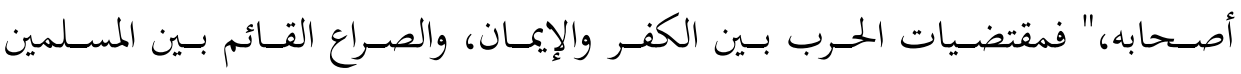

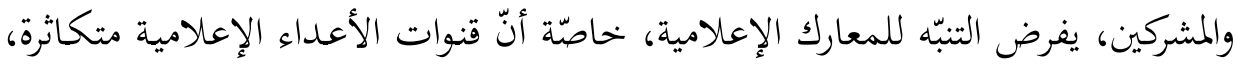

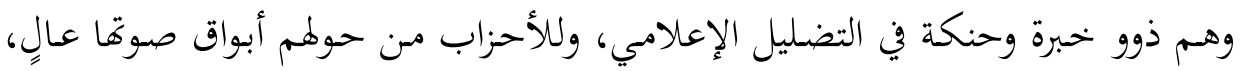

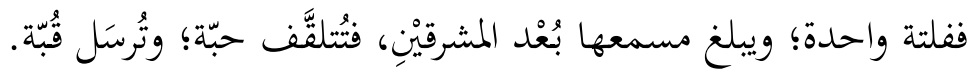
وأصل المعروف ما تعارف الناس على صلاحه في الشرع، مّّا عرّفه الله ورسوله وسلف

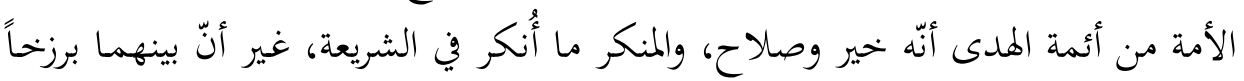

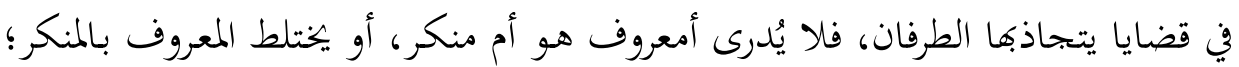

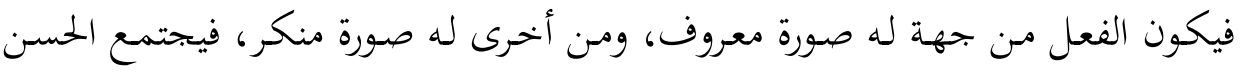

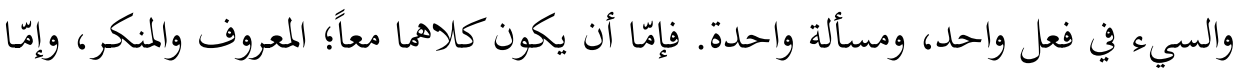
ينتفيان معاً.

فما من بُدّ لضابط يميز دقيق المعروف من شوائب المنكر، "وأصل هذا أن تكون محبة

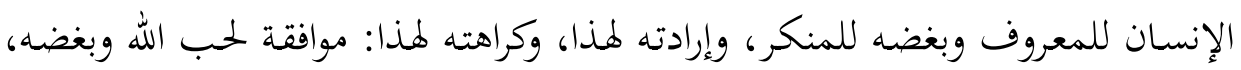

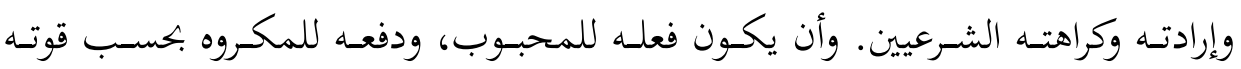

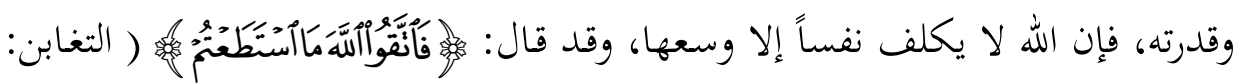

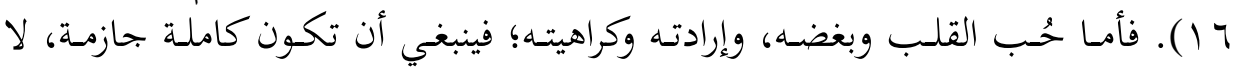


يوجب نقص ذلك إلا نقص الإيمان. وأمـا فعل البدن فهو بحسب قدرته، ومتى كانت

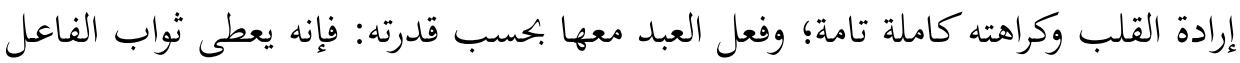

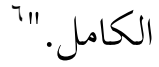

\section{Y r ت تفاوت مراتب النفع والضرر:}

من السنن الكونية الاختلاف والتباين. وتتباين الأجناس لعموم الناس، وإن قَلَّ منهم

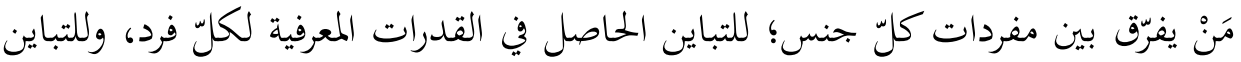

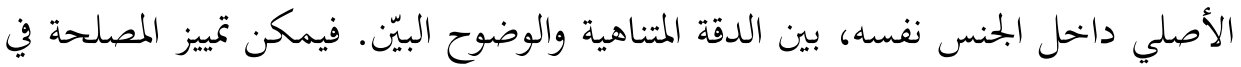

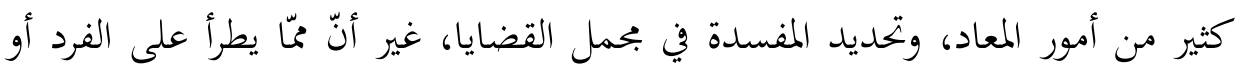

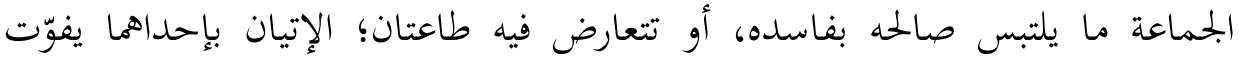

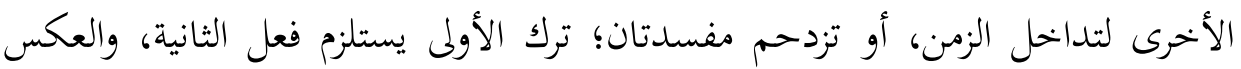

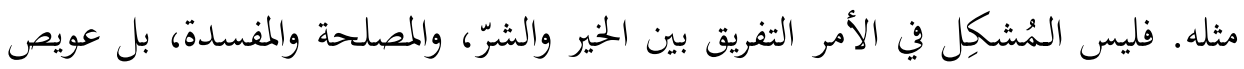

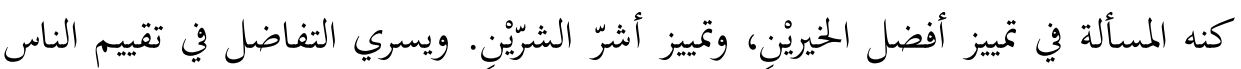

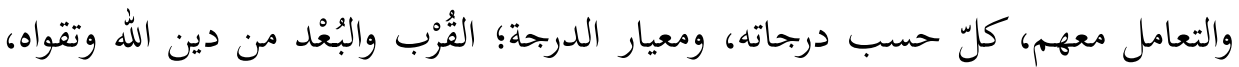

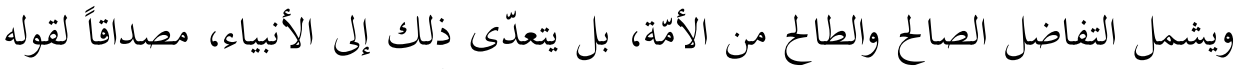

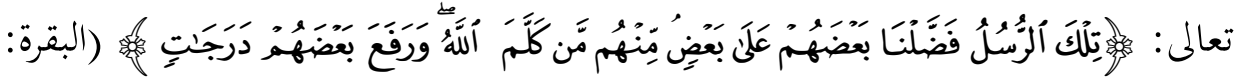

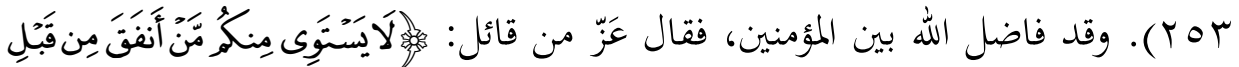

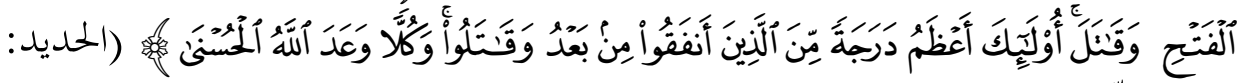

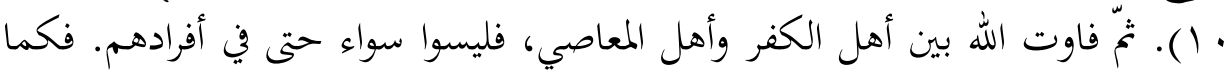

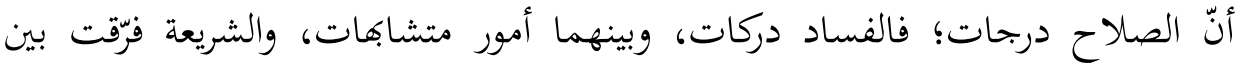

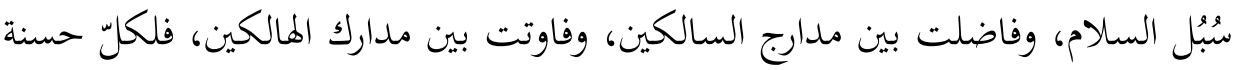
وزها، ولكلّ سيئة مثقالها.

وتترتيباً على ذلك؛ لا يُنظر إلى أهل الكفر أو البدع، أو المعاصي، أو الأخطاء على

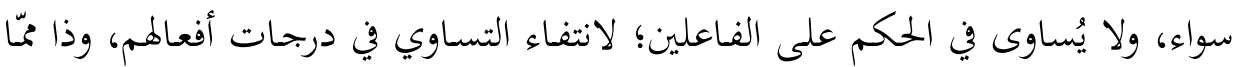

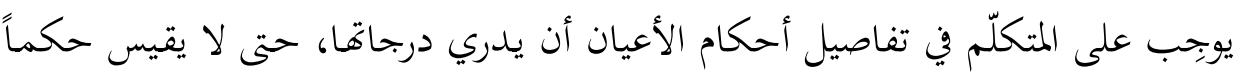




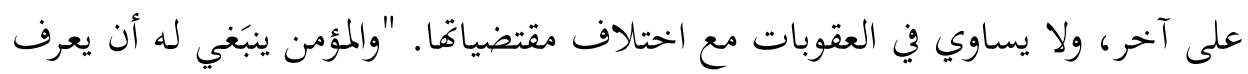

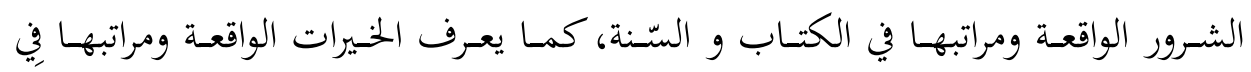

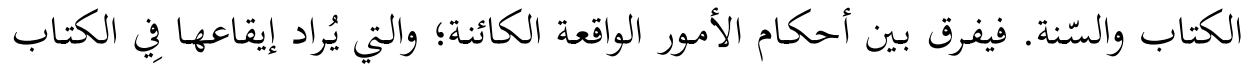

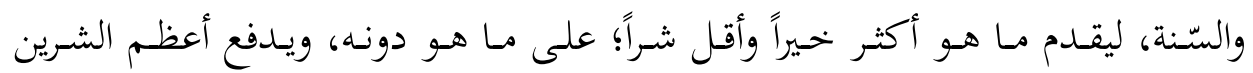

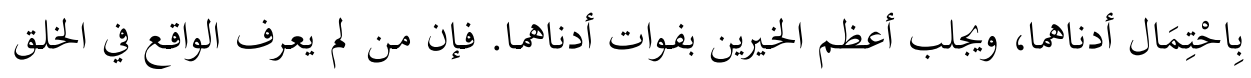

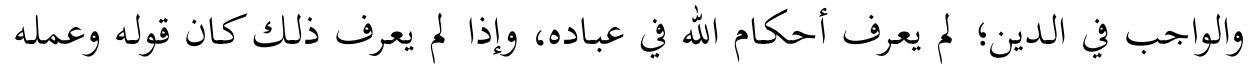

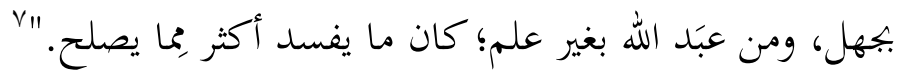
فشرط صحة العمل؛ العلم، وقصد المتابعة، وإخحلاص النية. وشرط صحة العلم؟؛

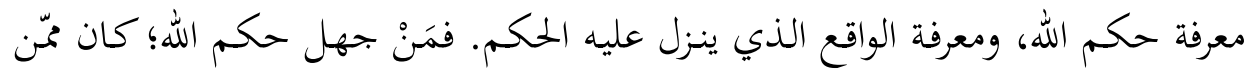

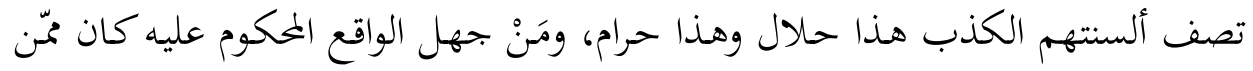

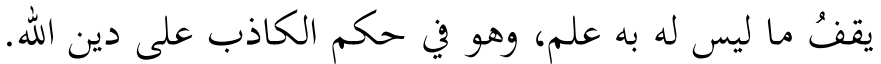

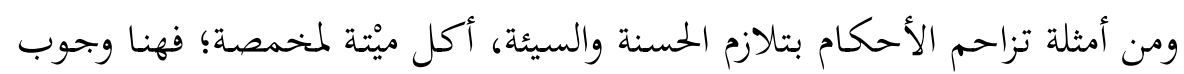

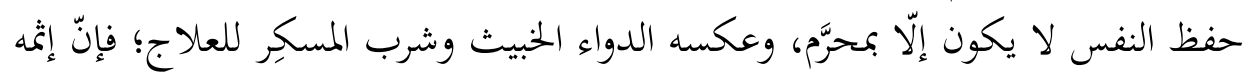

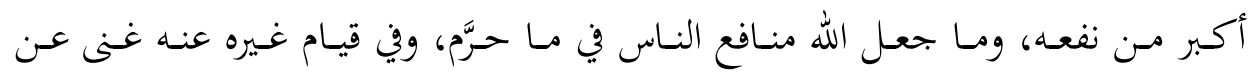

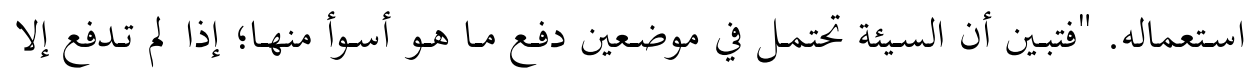

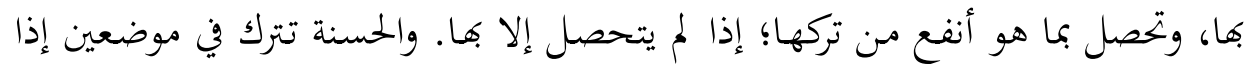

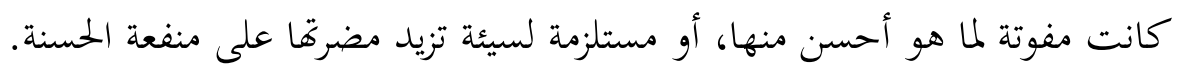
هذا فيما يتعلق بالموازنات الدينية؛ وأما سقوط الواجب لمضرة في الدنيا، وإباحة المحرم

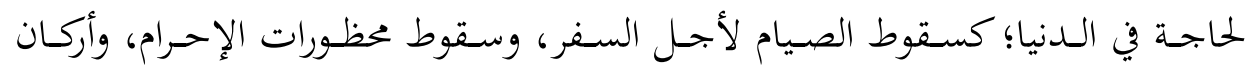

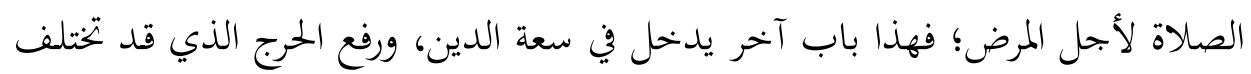

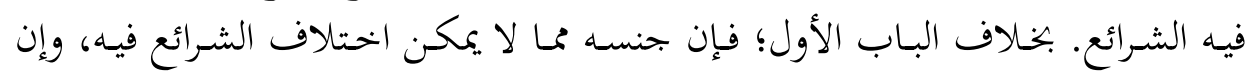

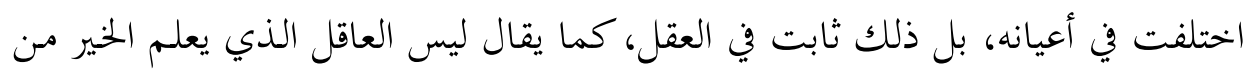

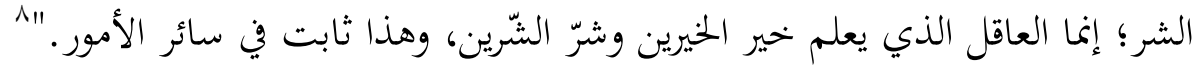

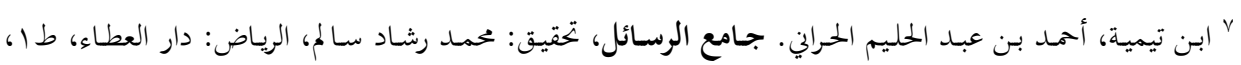

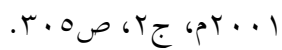

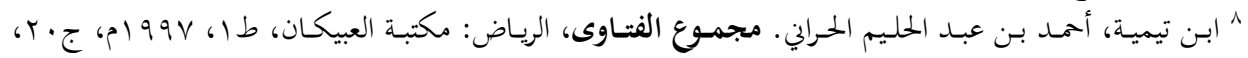


فالتزاحم وارد في أمور الدنيا والدين، وتخيير الأفضل وترك الأضرّ، يُبرِئ ذّّة صاحبه

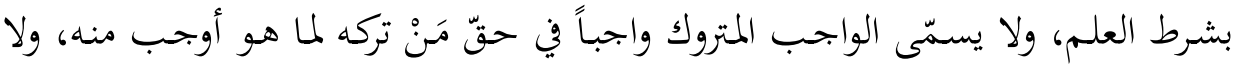

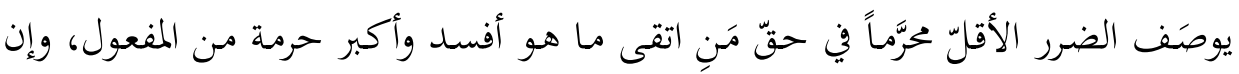

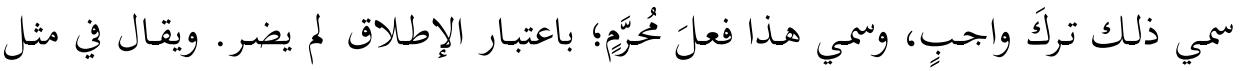
هذا ترك الواجب لِعُذر؛ وفعل المحرم للمصلحة الراجحة؛ أو لضرورة أو لدفع ما هو أكبر لهرب

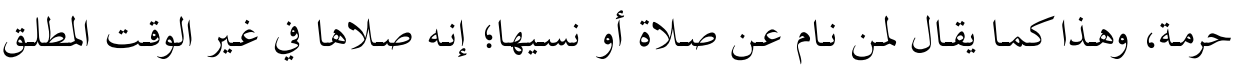

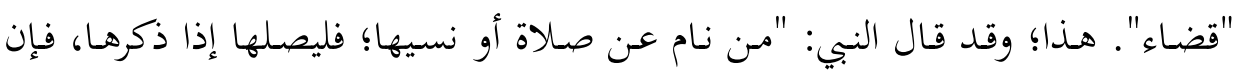

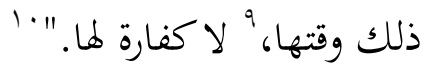

فالشريعة لم تفرض أن يكون المأمور به خيراً مطلقاً، ولا المنهيّ عنه شرّاً مضاً، بل

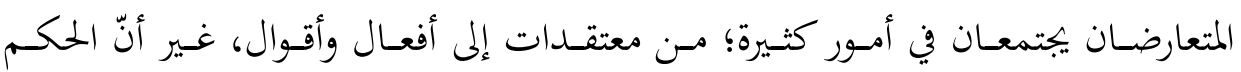

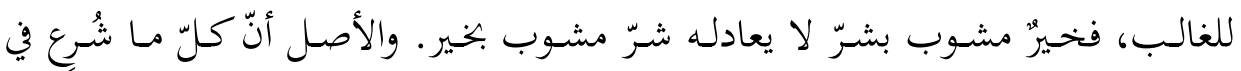

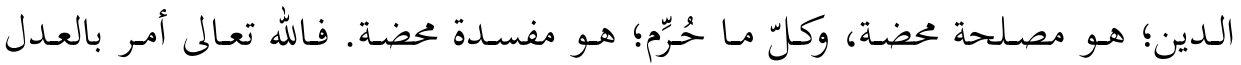
والإحسـان في أدقّ الأمسور وجليلها، وفهى عن البغي والمنكر والعـدوان في حقير الأمسور وجَلَيلِها، فكانت القاعدة أنّ الطيّب حلال، والفاسد حرام، حتى في ما لا يُعَلم نصّه. وإن كان الطيّب الصرف نادراً، كما أنّ الفاسد بالكلّ قليل، فالمكروه قد يجتمع معهد

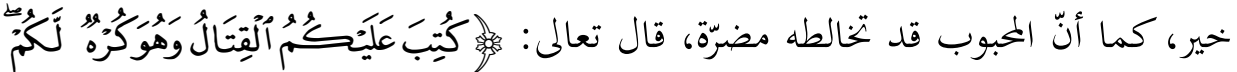

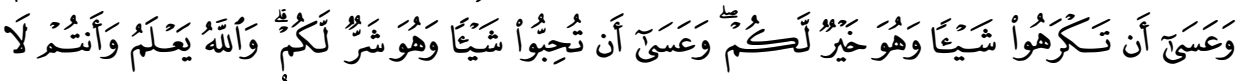

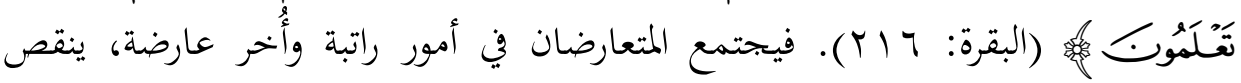

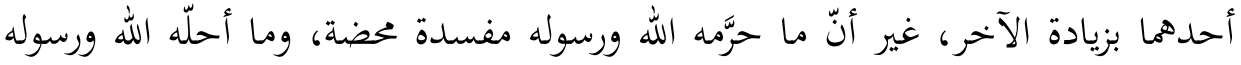

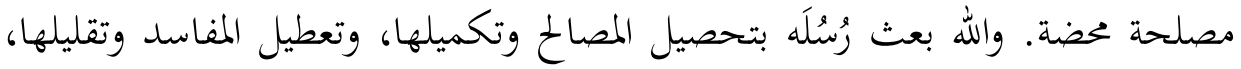

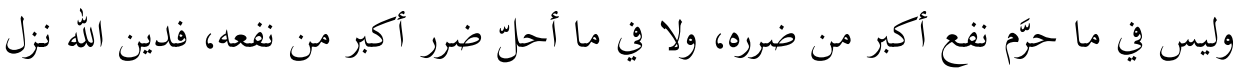

9 الدارمي، عبد الله بن عبد الرحمن أبو محمد. سنن الدارمي، تحقيق: فواز أحمد زمرلي، وخالد السبع العلمي، بيروت:

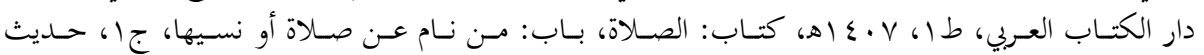

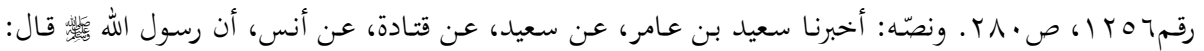

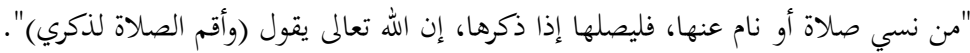

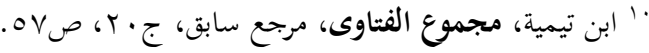




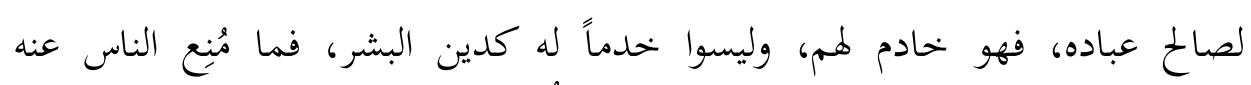

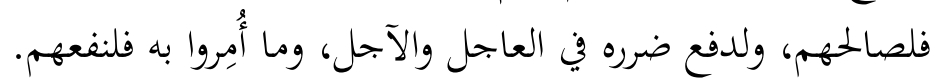

وغالب زلّات الناس في معرفة شرّ الشرّيْنِ؛ لأنّ خيار أحد الخيزيْنِ لا يتبعه إثم، ولا

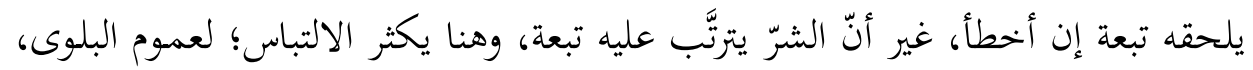

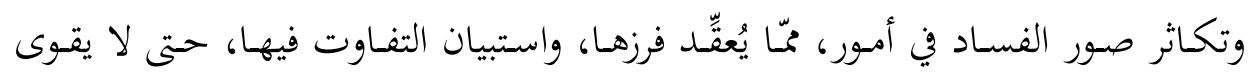

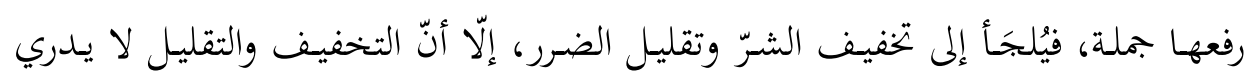

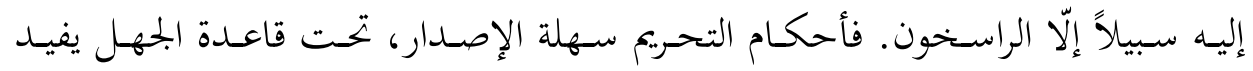

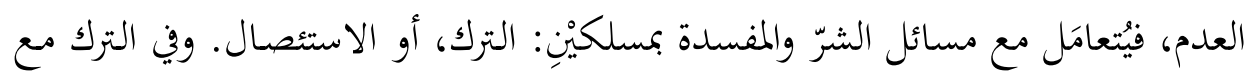

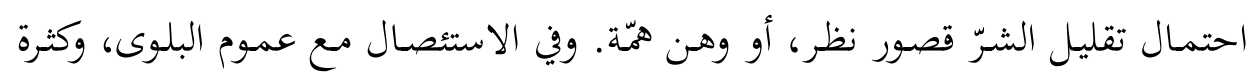

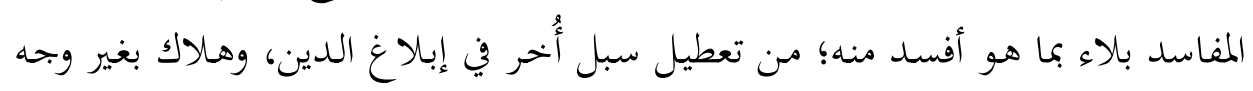
حقّ. فالتفطّن للرخص، وتمييز دقيق مسالك الفتوى في إصدار الحكم، ومراعاة ملابسات

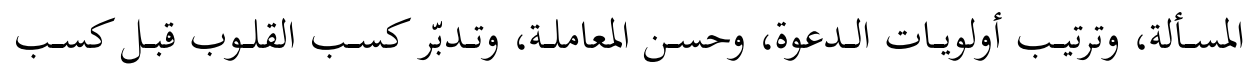

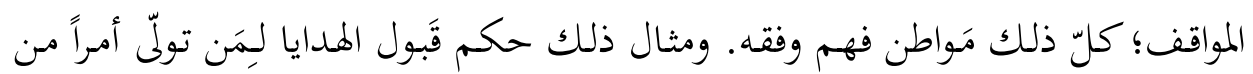

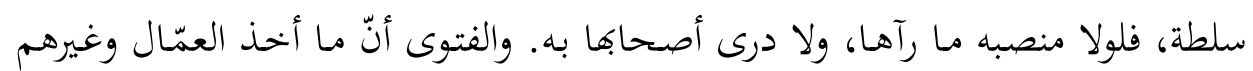
من مال المسلمين بغير حقّ؛ فلولي الأمر العادل استخراجه منهم؛ كالهدايا التي يأخذوفها

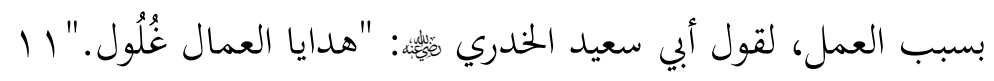
ومن التعارض الحاصل بتزاحم الأحكام الدنيوية والأخروية تولّي منصب عمل مباح،

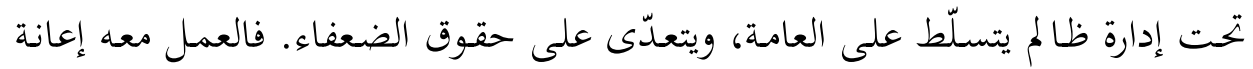

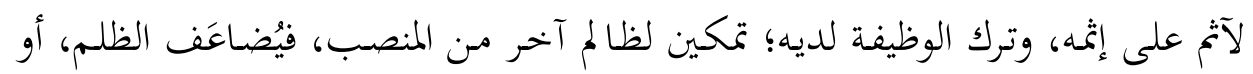

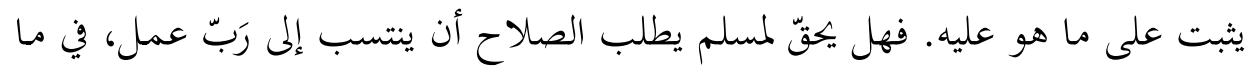

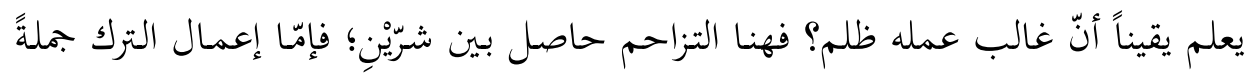
"' الألباني، محمد ناصر الدين. إرواء الغليل في تخريج أحاديث منار السبيل، بيروت: المكتب الإسلامي، طץ، 
وتفصيلاً، فيُعََّض منصبه بشخص آخر، ولن يعدم رَبّ مال أو مسؤول أو سلطان خدماً

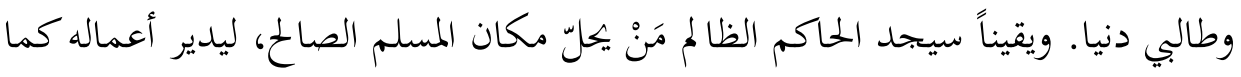

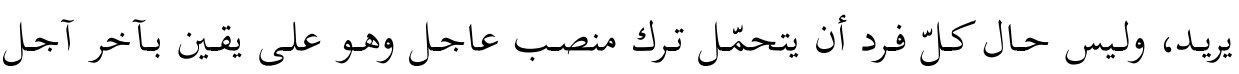

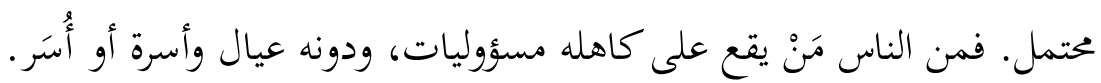

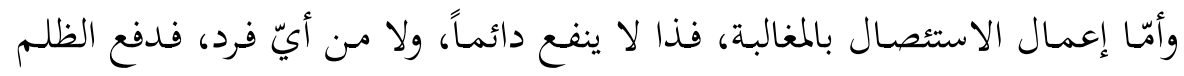

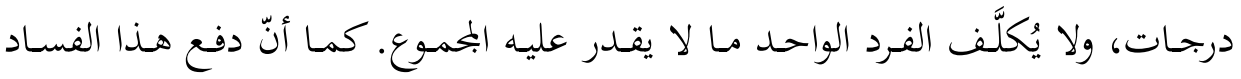

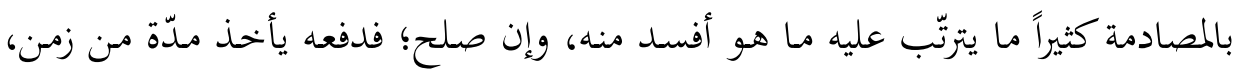

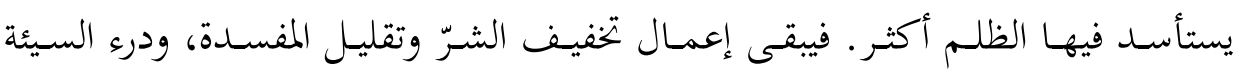

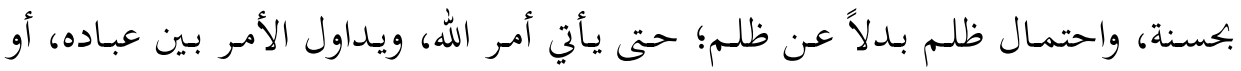

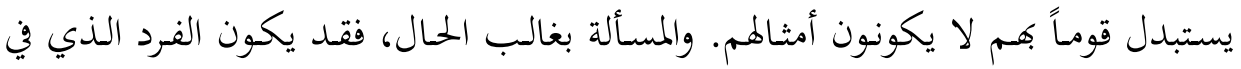

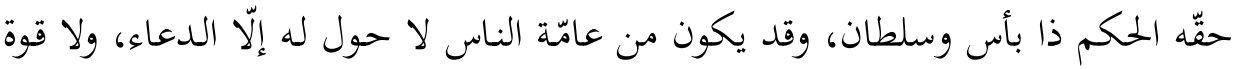

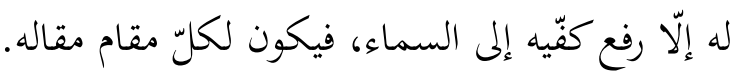

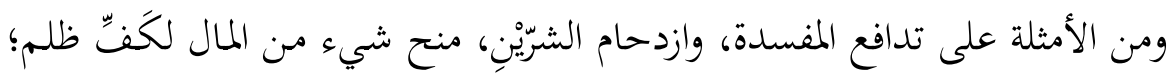

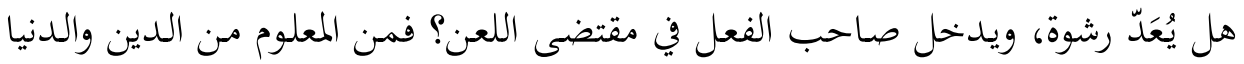

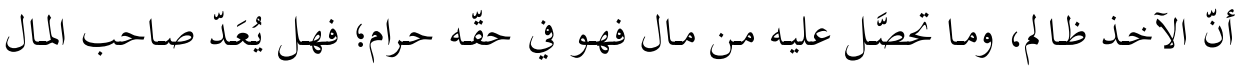

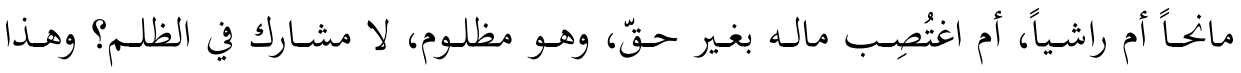

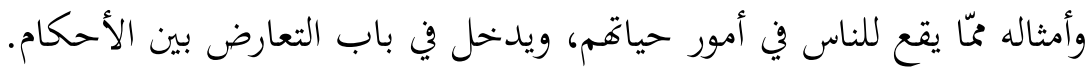

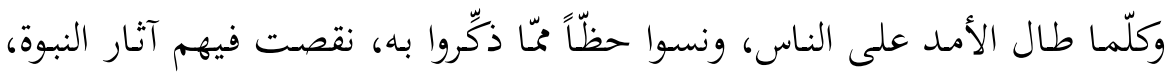

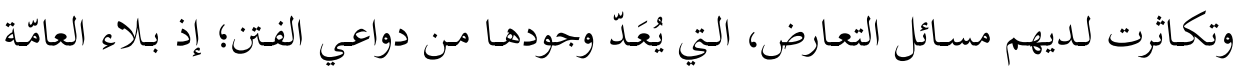

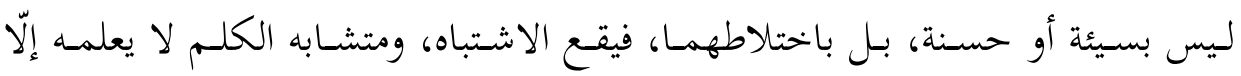

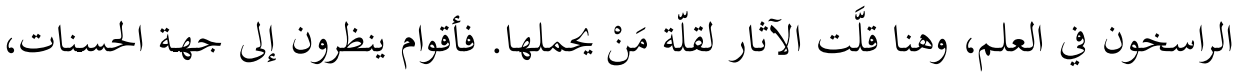
فيأحذاون بالجواز تعليلاً بها؛ وإن تضمّنت سيئات عظيمة. وطائفة تنظر إلى السئ السيئات؛

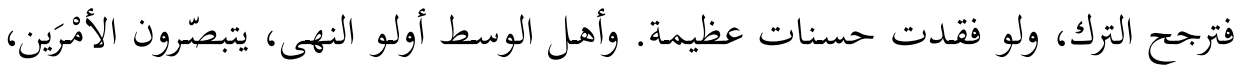

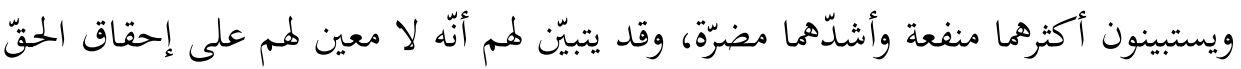




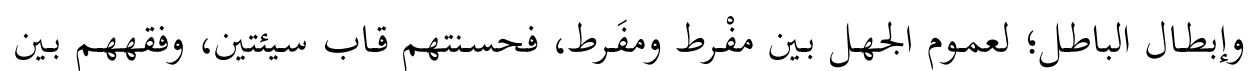
أحاديتين: سالبة، وموجبة.

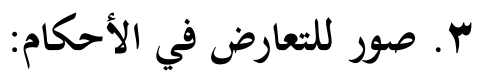

التعارض في الأحكام هو أن يتقابل الواجب والمحرَّم، والجحائز والممنوع، والأمر والنهي

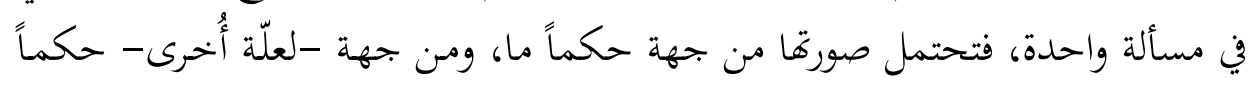

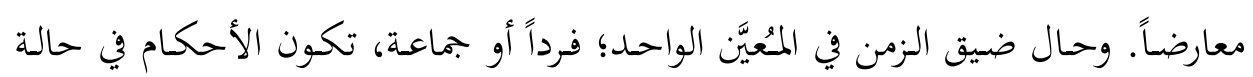
ازدحام؛ فالتعارض ينتج منه التزاحم.

تقع في المستجدات أمور، تكون لما أحكام راتبة في ثبوتا وسقوطها؛ وهي الأحكام

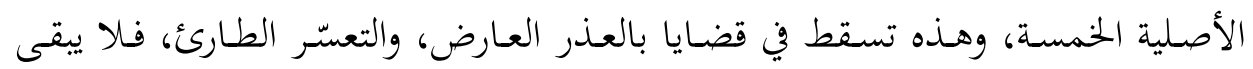
الواجـب واجباً ولا المستحب كذلك، ويستحب للعارض ويوجب مـا لا يكون في أصله راتباً. ويقع الغلط أحياناً بعدم التفريق بين الراتب والعارض، وكثيراً في اعتقاد عدم تغيّر

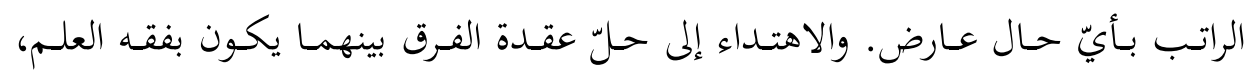
والتبصّر في دقائق المسائل، وإعمال الموازنة بين الراتب والعارض من جنس حكىم واحدل: الواجب على الواجب، والمستحب على المستحب، ووجوب الفِعْل مع وجوب التَّكك. والوجوب قد يُعتمد لأعيان الأحوال أو الأشخاص، فيرجح وجوبُّ في حال دون أخرى، وفي حقّ فرد بعينه دون غيره. ومثال ذلك حكم توليّ المسلم المجتهد في الإصلاح

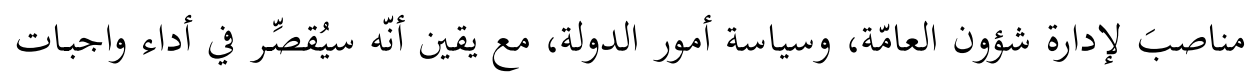

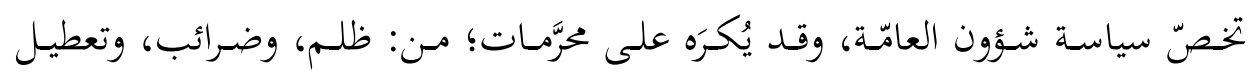

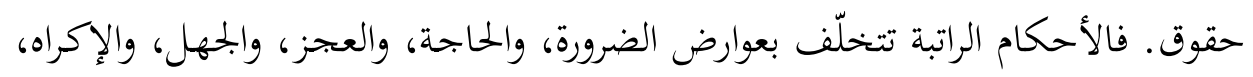
والحـرج، ونحوهـا، وهـذه العوارض قـد تكـون بيّنة، وقـد تخفى على بعضهـم. لـذا، حـال

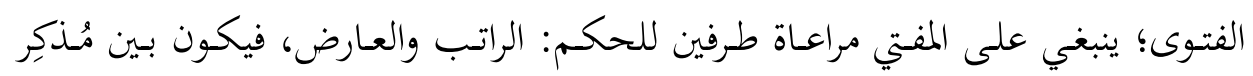

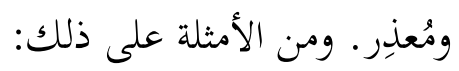
- - إعطاء الكفار مالاً؛ لدفع شرّهم عن المسلمين حال الضعف. 
- - بيع الثمار قبل بـدور صلاحها تبعاً (لبيعها بعد القطف، وتقدير ثمنها عـاجلاً

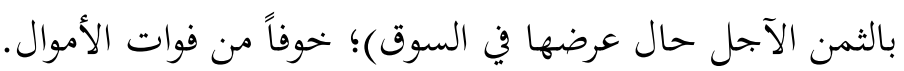
- ما يحتاج إلى بيعه يجوز بيعه، ولو كان معدوماً؛ كالمنافع.

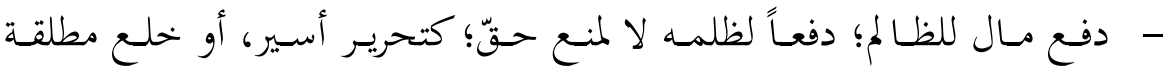

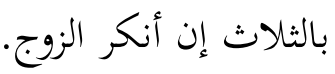
- السفر بالأجنبية؛ خوف ضياعها، أو تعرّضها لضرر. - قضاء دين بمال فيه شبهة. - تسليم متهم لقاضٍ، أو سلطات، أو حاكم ظالم، مع اليقين بأنّه سيُبغى عليه، ويُتعدّى حدود الله فيه؛ بأن تكون عقوبته أكثر من جرمه، أو بلا ثبوت الجرم أصلاً.

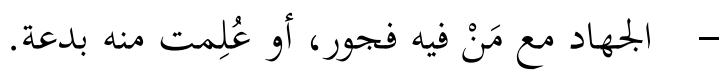
- - الصلاة خلف صاحب هوى أو مبتدع. - بقاء مَنْ أسلمت حديثاً مع زوجها الكافر وأولادها.

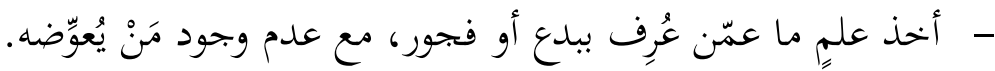

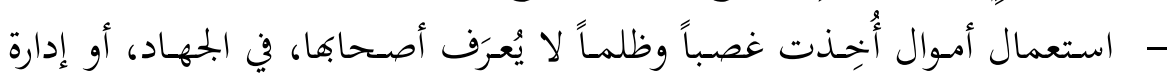
الشؤون العامّة. - قََبول ميراث يُعَمَ يقيناً أنّه كسب حرام.

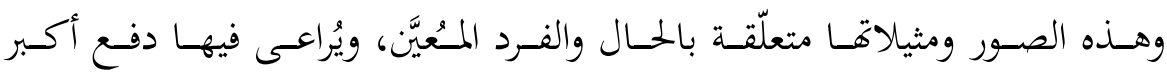
المفسدتين، وتحصيل أكبر المصلحتين، مع النظر إلى أصناف المناهي الشرعية، وترتيبها. وأنواع التعارض بين الأحكام تُقسم من جهة المكلّف، ومن جهة المتعارضات على النحو الآتي:

أ. من جهة المكلّف: يكون ذلك بترك الحسنة، أو فعل السيئة؛ إمّا لغلبة فيُعََر،

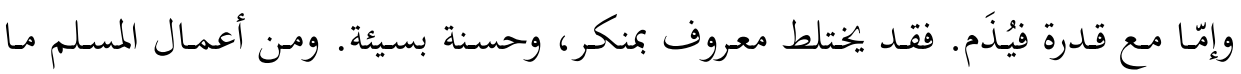

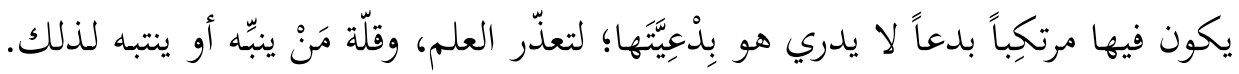

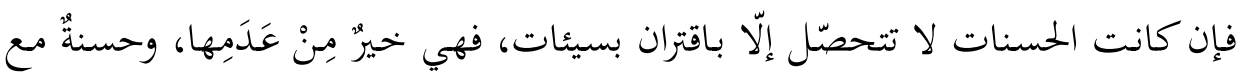




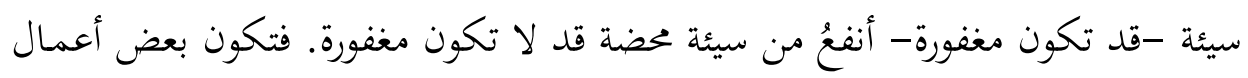

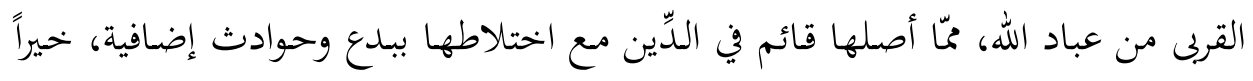

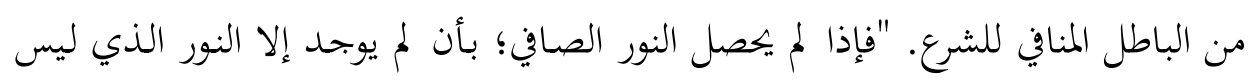

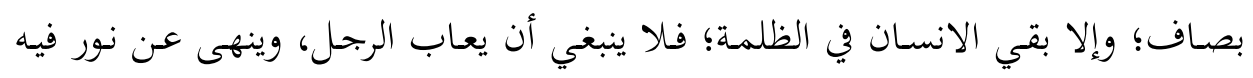

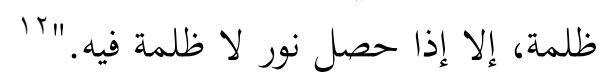

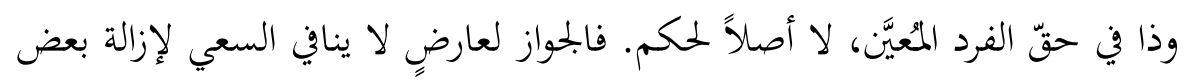

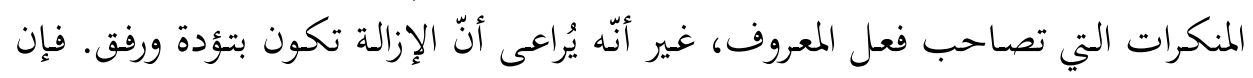

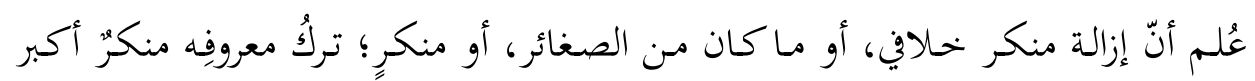

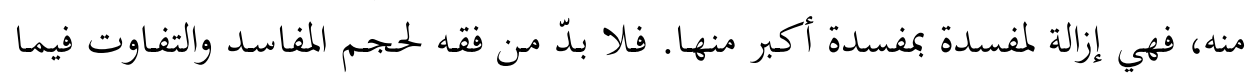

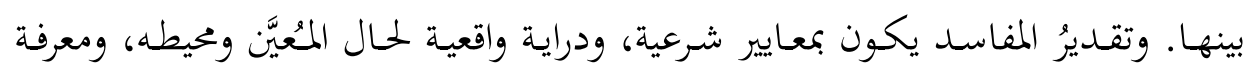

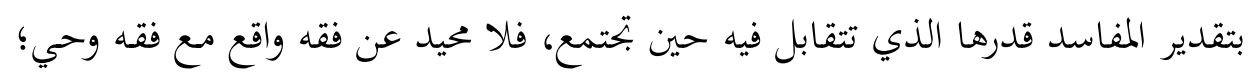
ليجلو النظر ، ويصح التنظير.

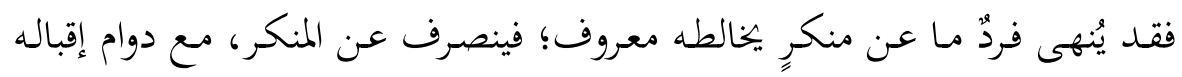

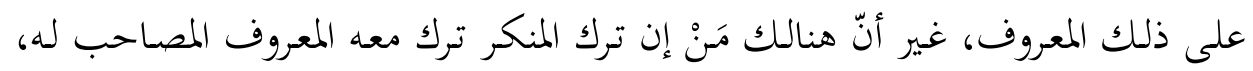

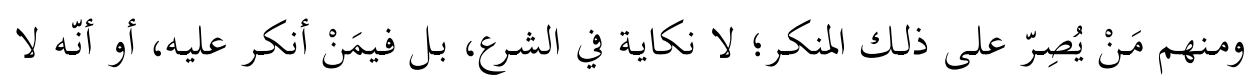

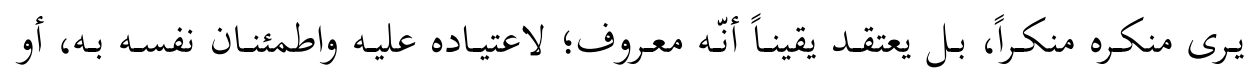

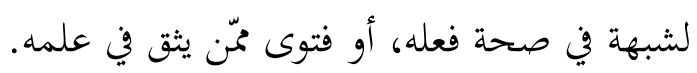

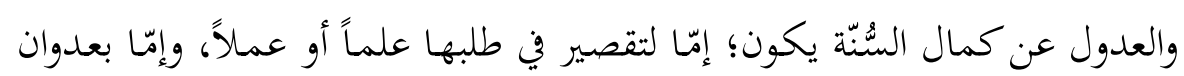

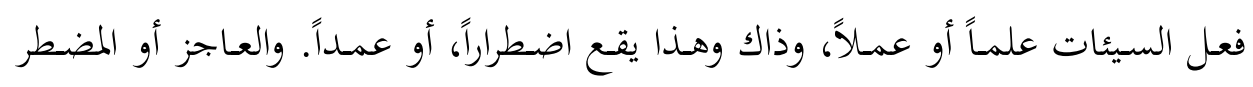

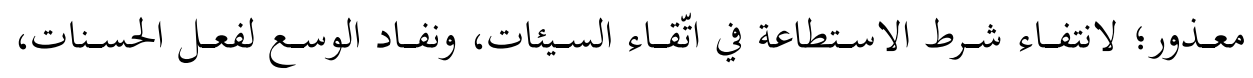

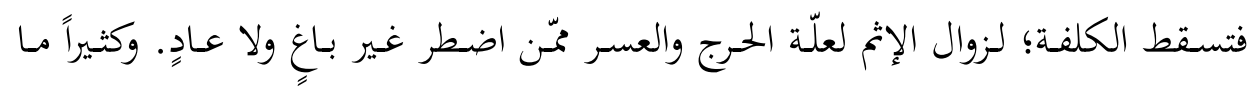

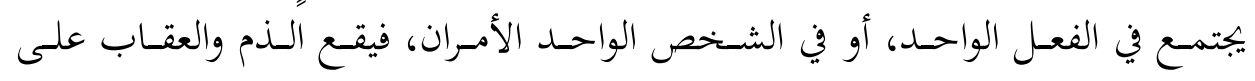

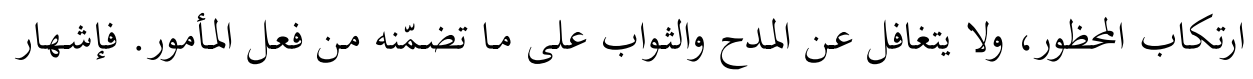

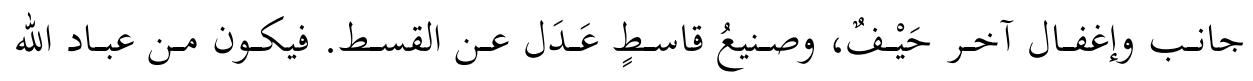




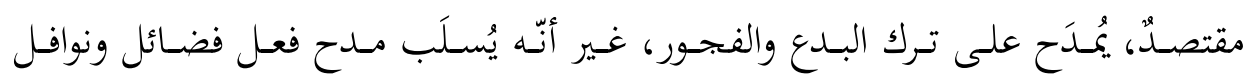

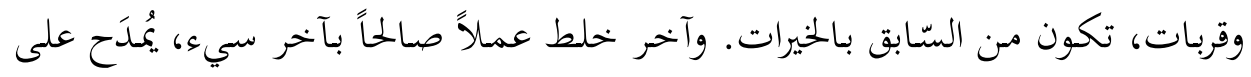

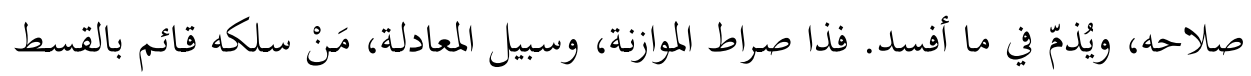
الذي أنزل الله له الكتاب والميزان. ومن صوره: قراءة القرآن جماعة؛ وهي فعل حسنة راجحة مع إتيان سيئة دوها في مفسدة ترك الحسنة.

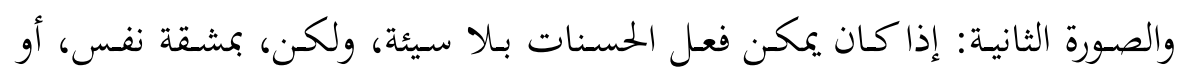

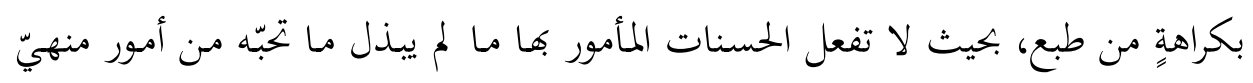

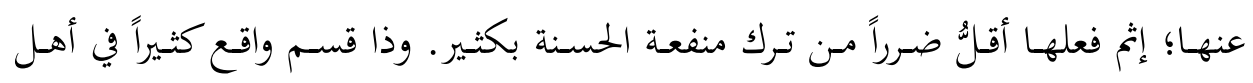

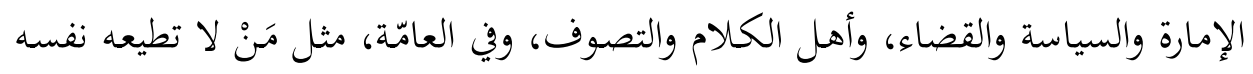

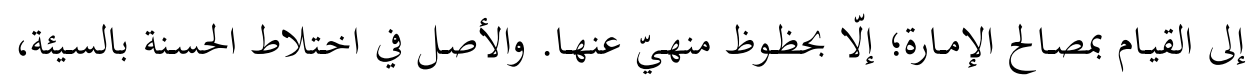

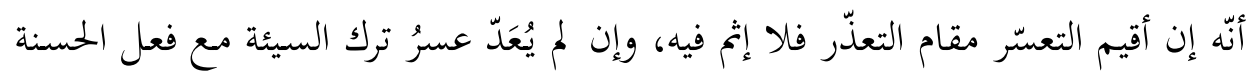

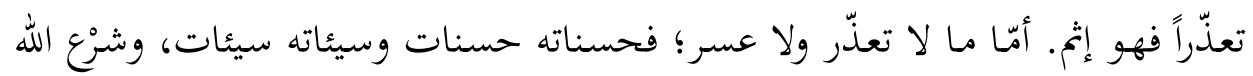

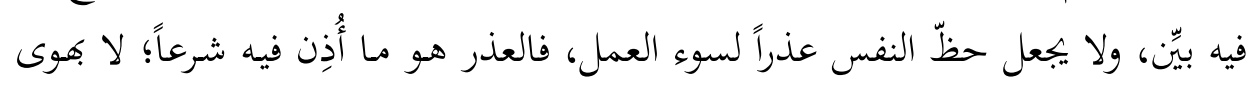
صاحبه.

ب. من جهة المتعارضات: وذلك بأن تتوارد حسنتان مع تزاحم الزمن، فلا سبيل

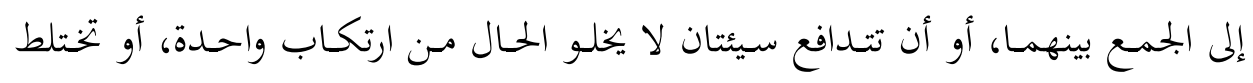

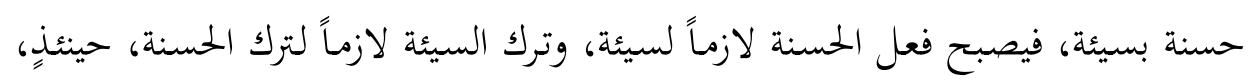

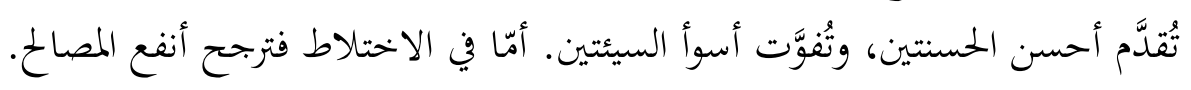

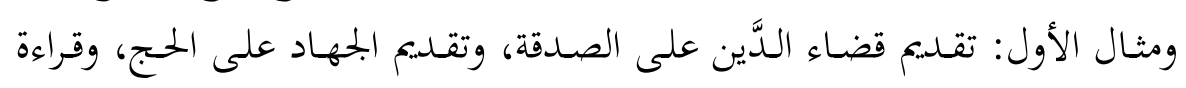
القرآن على الذكر. ومن الأمثلة على الثاني: تقديم سفر المرأة بلا يُحَرَم على بقائها بدار حرب، وتقديم

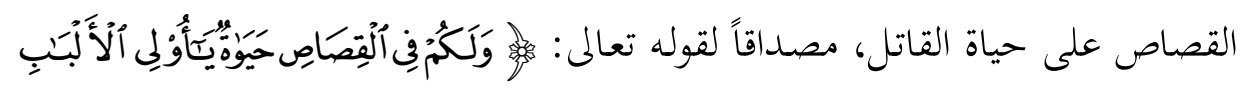

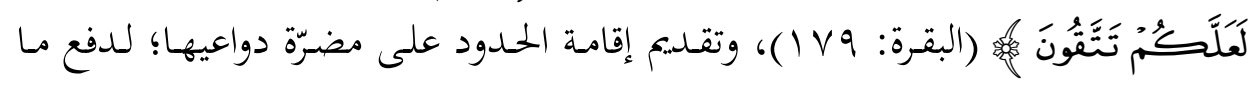
هو أضرّ منه. 


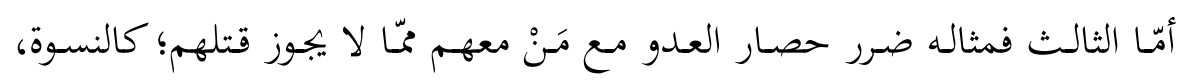

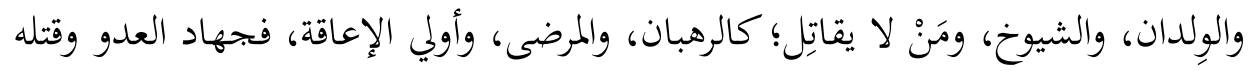

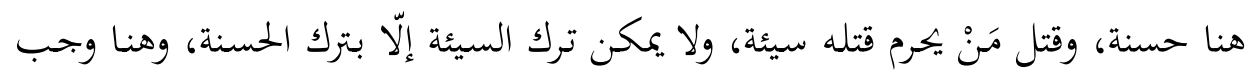

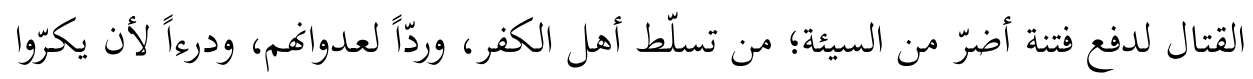

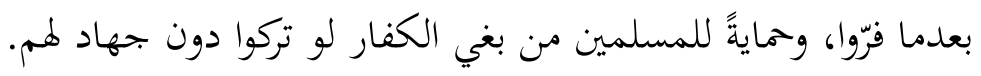

\section{ثانياً: تزاحم الأحكام في تصنيف الناس}

من الإشكالات المطروحة في الساحة الدعوية والعلمية بين المسلمين، قضية التطرّف

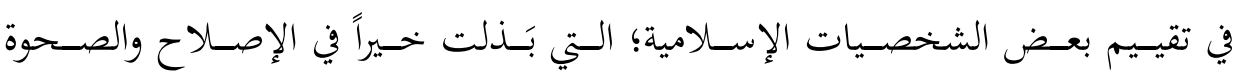

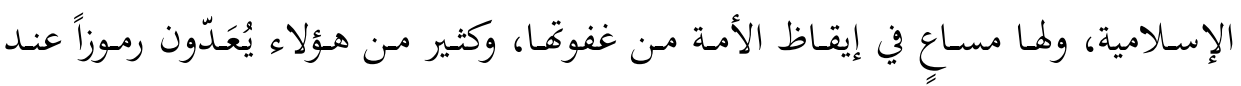

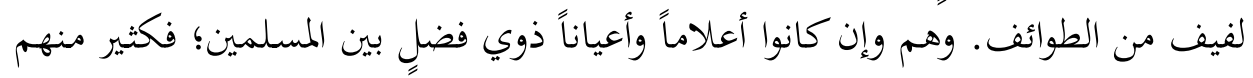

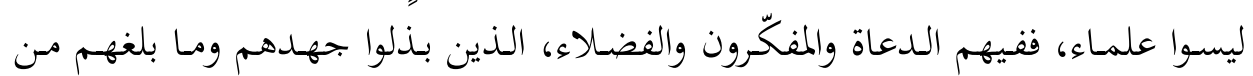

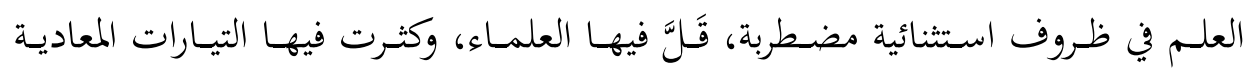

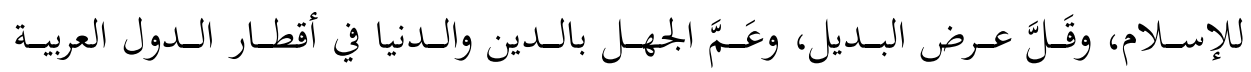
والإسلامية.

لأجل ذاك قام أولئك الأفاضل لمنابذة الزحف التغربي ومقارعته، وردّ طيش أولئك

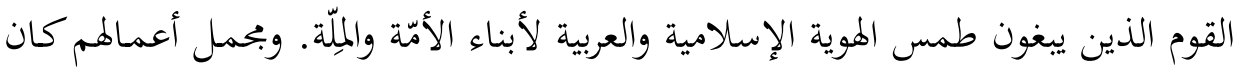

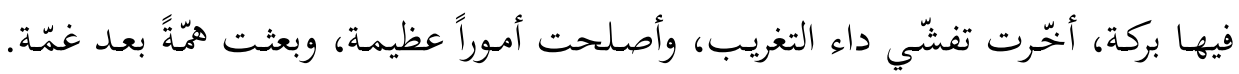

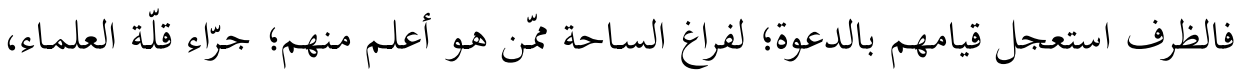

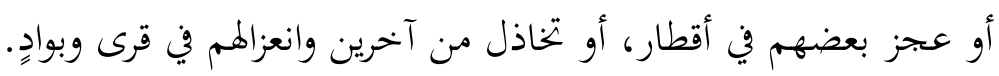

ووقوع أعـام في أنواع مـن الأخطاء أو البدع أو الشطحات، ليس بغريـب. فكثير

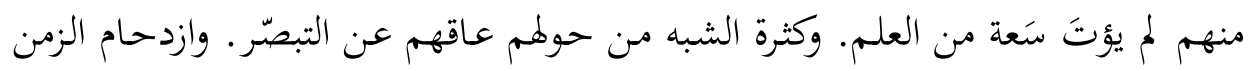

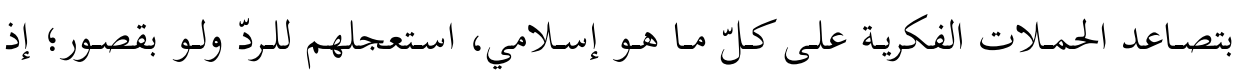

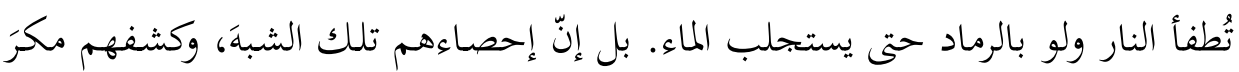


أبناء الجلدة من المنافقين والمغتريّين، بما معهم من علوم الغرب؛ مهَّد لطلبة العلم والعلماء

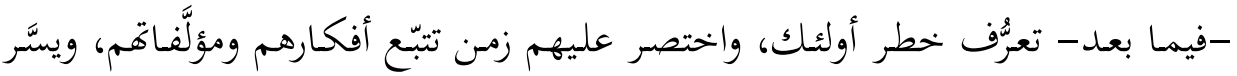

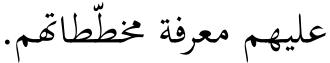

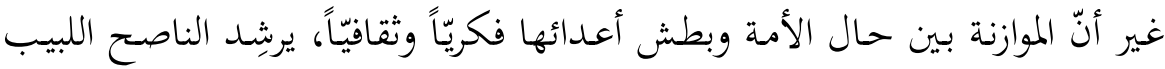

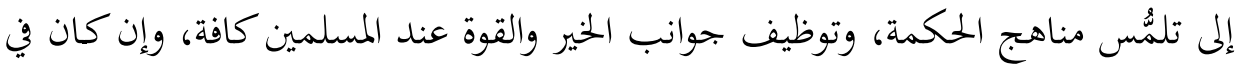
بعضهم تقصير، وتضعيف جوانب الجهل، والتعصّب بالتناصح الأخوي، والتدرّج المتفاعل

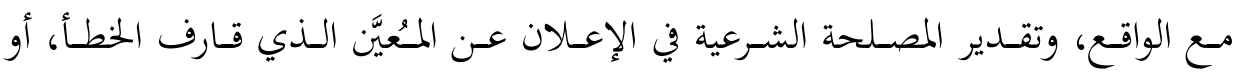

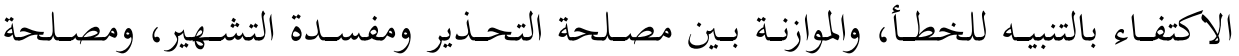
النصيحة ومفسدة الفضيحة.

وتفصيل ذا يكـون بييان التزاحم الحاصل في تقييم الشخصيات والطوائف عامّة

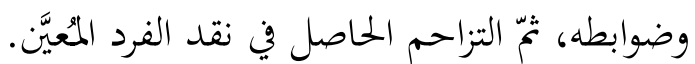

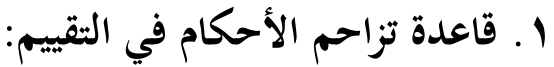

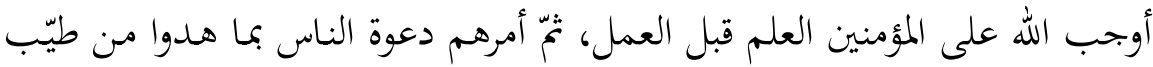

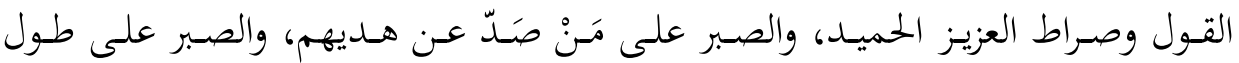

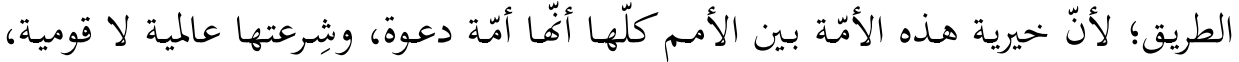

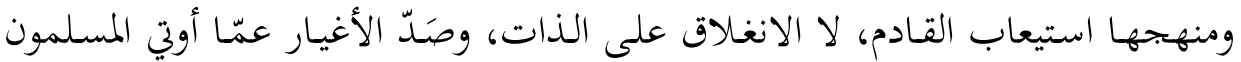

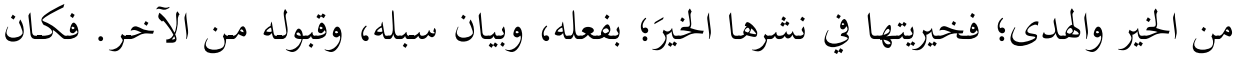

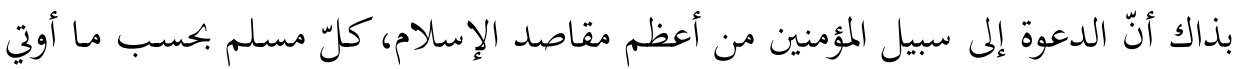

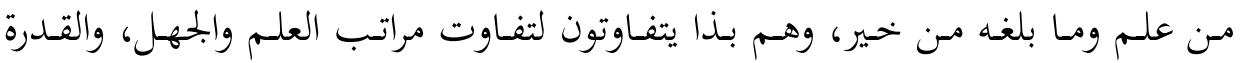

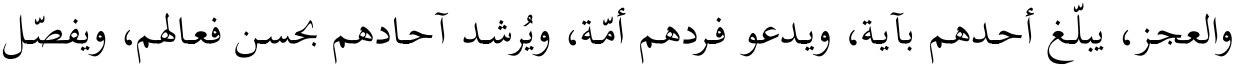

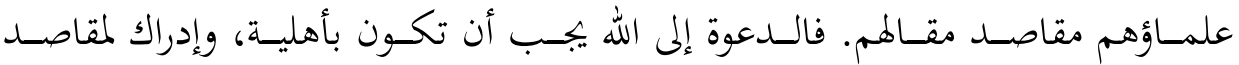

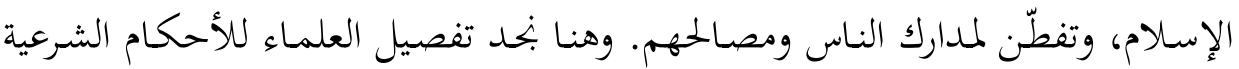

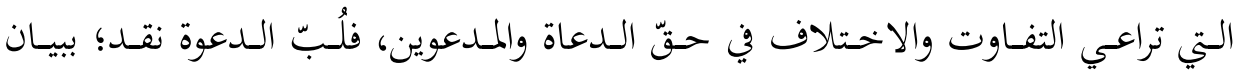

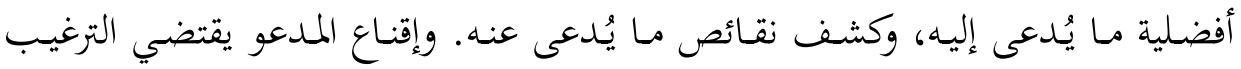
والترهيب، وتعليل أحقية الحقّ، وردّ شبه الباطل، والجحدال في مَواطن. 


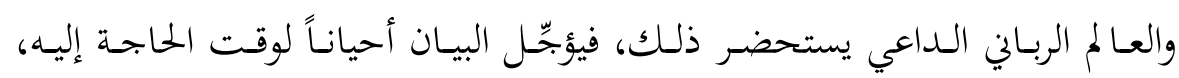

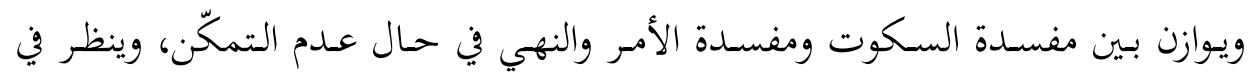

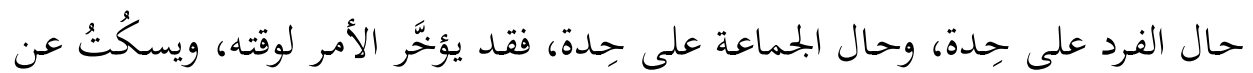

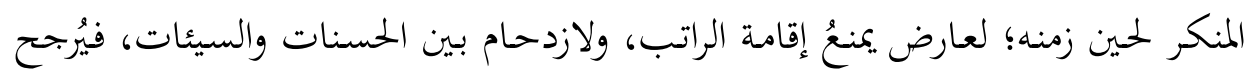

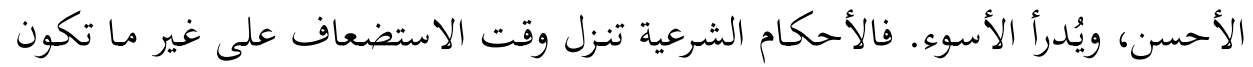
وقت القوة والنفوذ، ويُفتى للعاجز على غير ما يكون الأصل مع القـادر، فيكون حـال

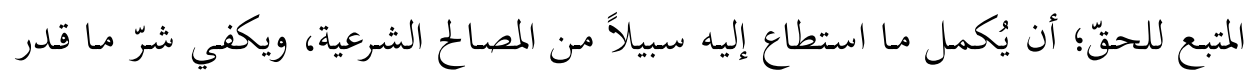

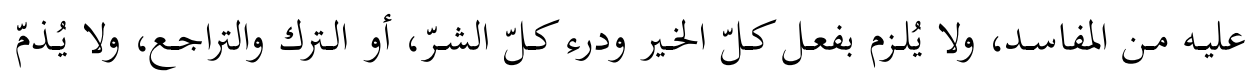

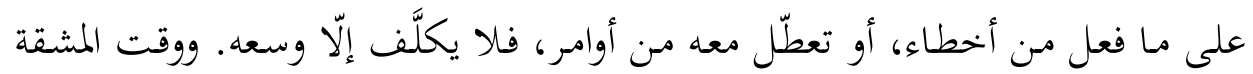

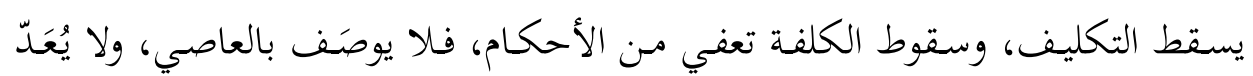
مقترفاً لسيئة، وخطؤه مغفور.

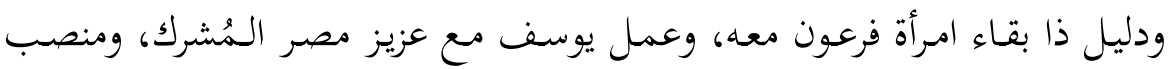

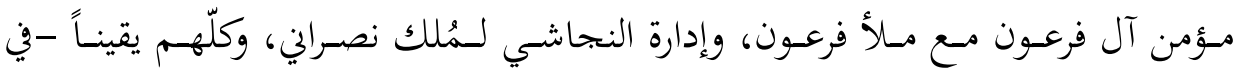

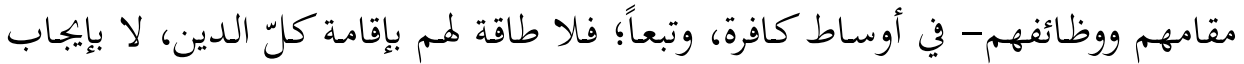

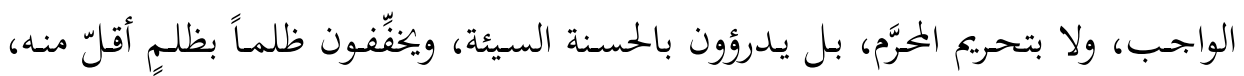

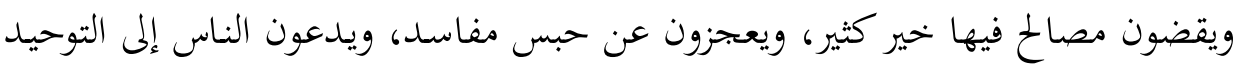

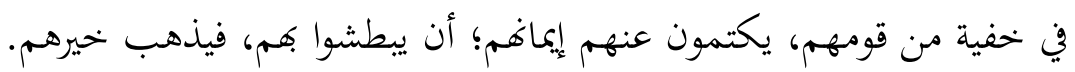

فما لا يُقدر على كلّه لا يُترك جُحلّه، ولا يُلزم بالإسلام كلّه مَنْ لا يقدر على جزئه،

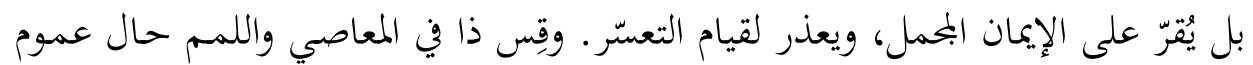

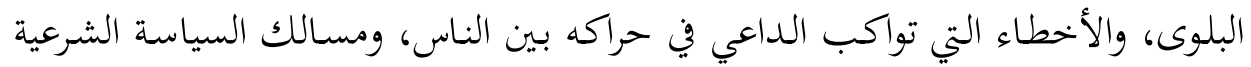

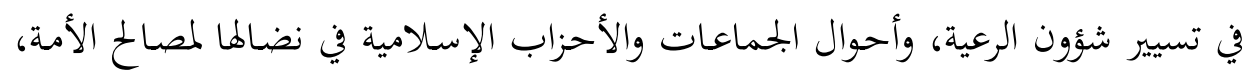

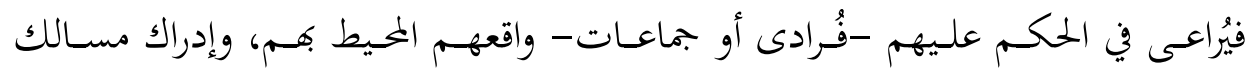

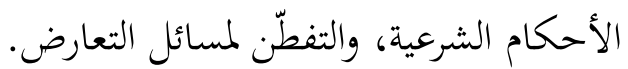

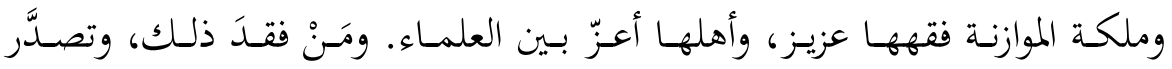

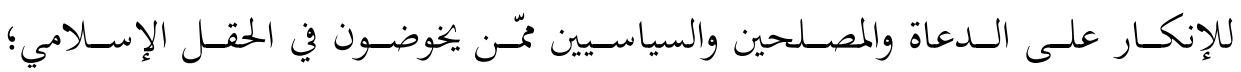




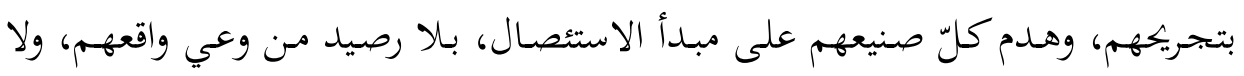

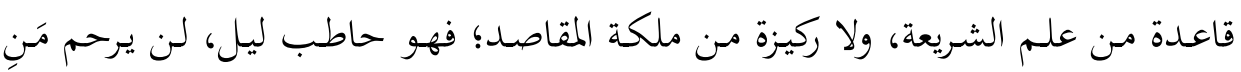

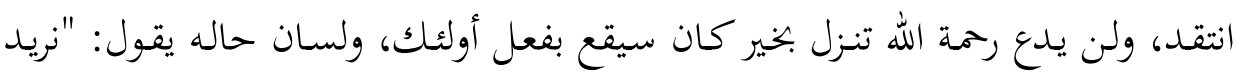

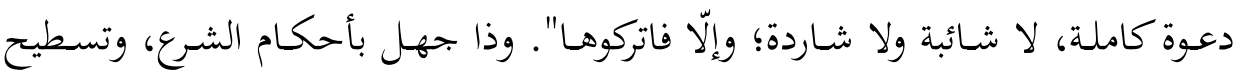

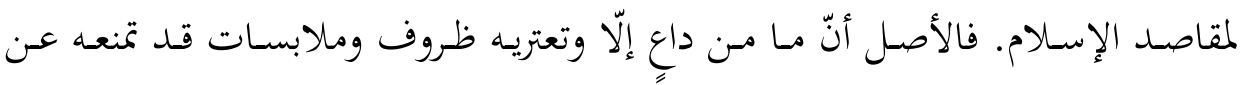

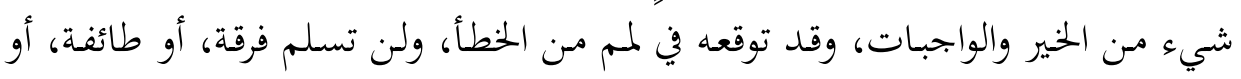

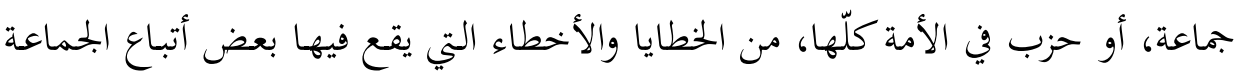

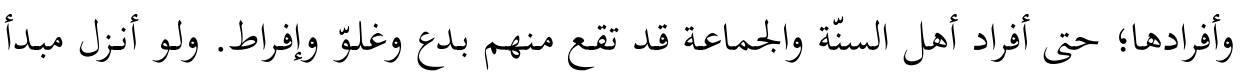

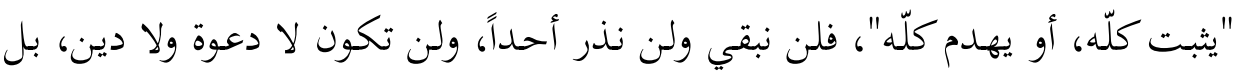

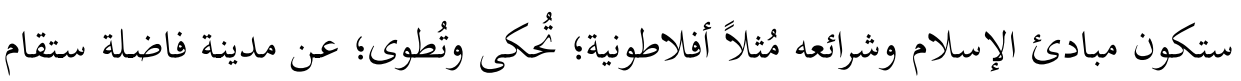

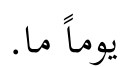

فصحيح الدعوة بالراجح وليس فقط بالخالص، والإيمان يقبل بالإجمال، ثُّ يليه أمور

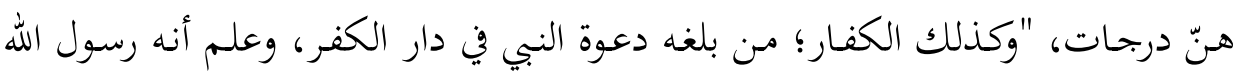

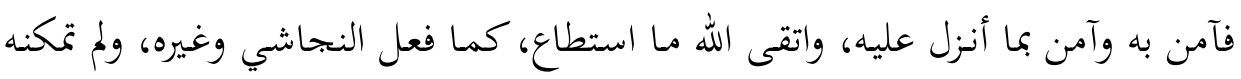

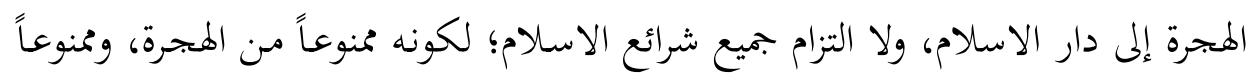

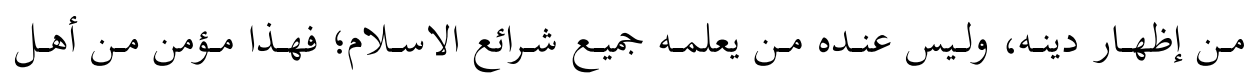
الجنة." آنار

ومن لطائف فقه التعارض، وإعمال الموازنة حال تزاحم الأحكام الشرعية في الدعوة

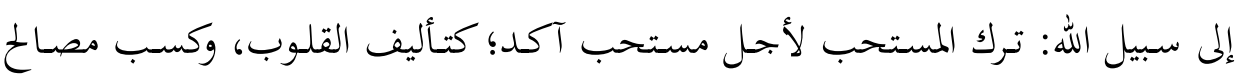

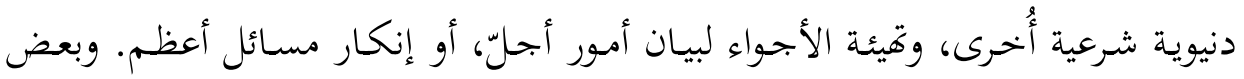

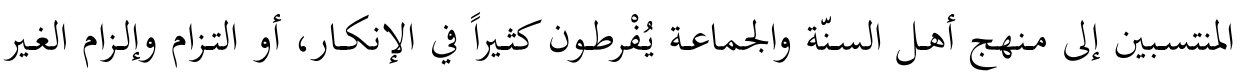

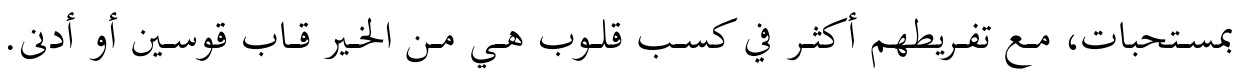

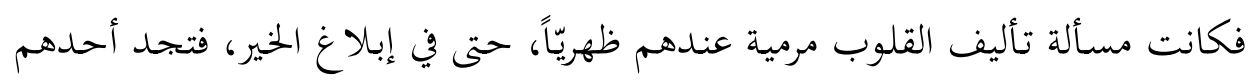




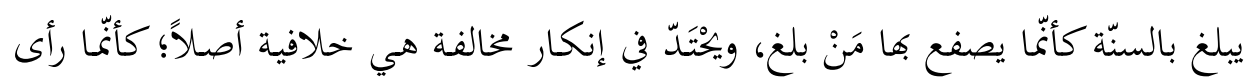

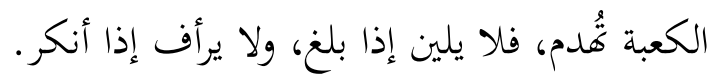

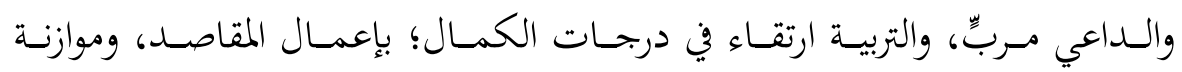

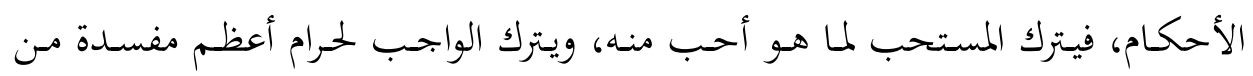

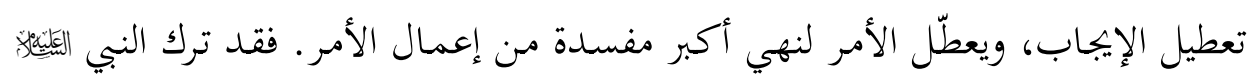

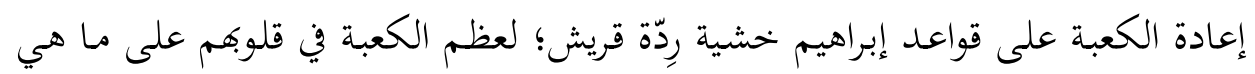

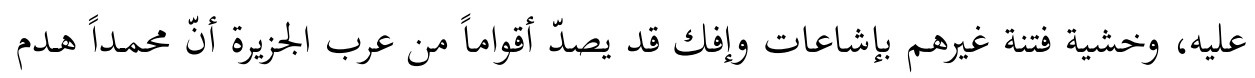

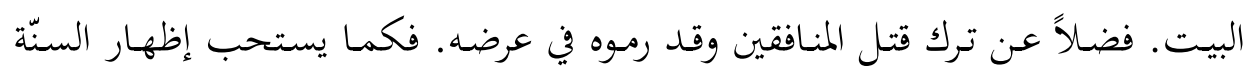

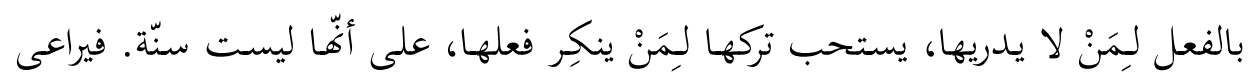

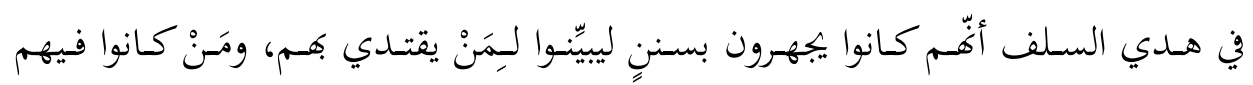

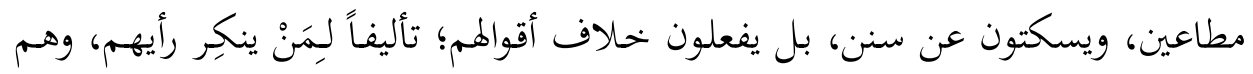

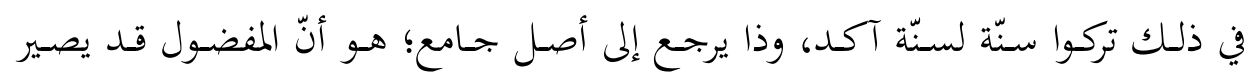

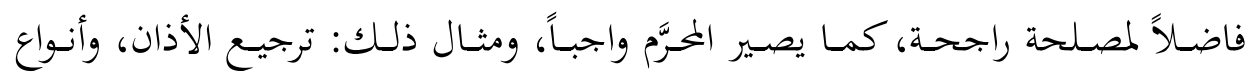

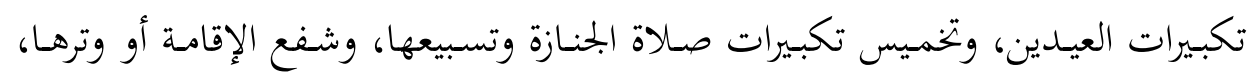

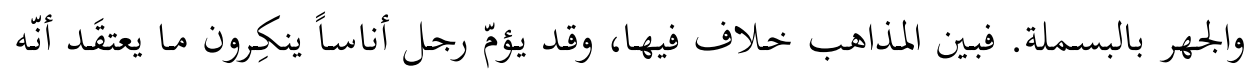

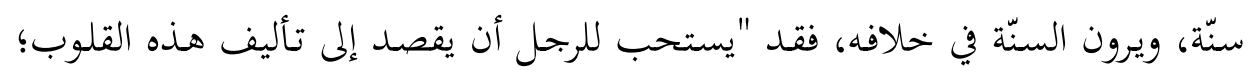

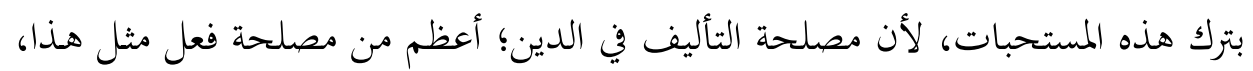

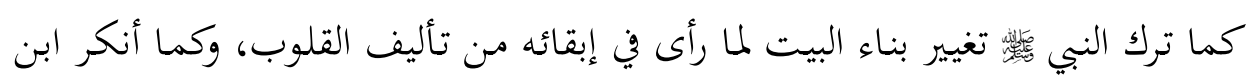

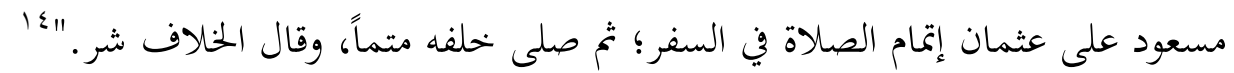

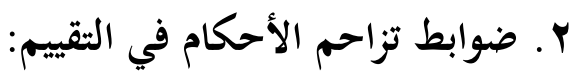

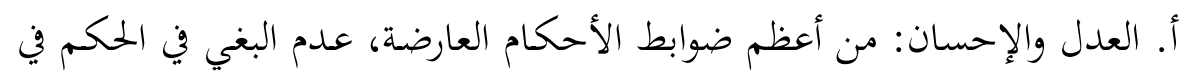

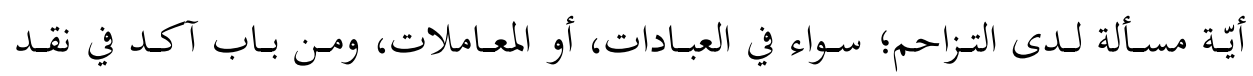

؛' ابن تيمية، أممد بن عبد الحليم الحراني. القواعد النورانية، تحتيق: عبد السلام عمد علي شاهين، بيروت: دار

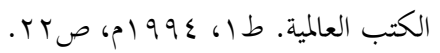


الناس، أو الردّ عليهم، أو الدعوة لهم، أو التنبيه لغيرهم. فالدعوة بالأمر بالمعروف والنهي

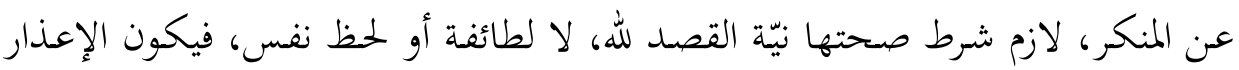

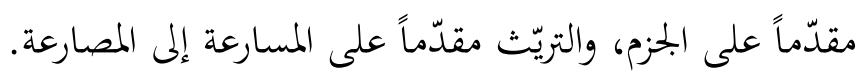

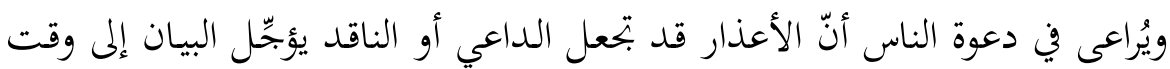

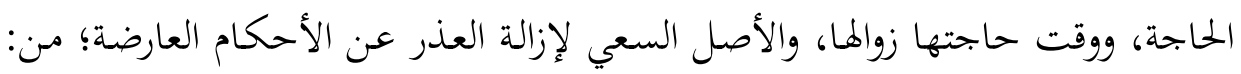
جهل، أو عجز، أو إكراه. "ومعلوم أننا إذا تكلمنا فيمن هو دون الصحابة، مثله مثل الملوك

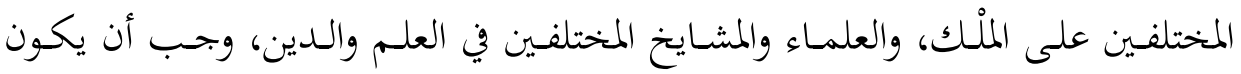
الكلام بعلم وعدل، لا بجهل وظلم، فإن العدل واجب لكل أحد، وعلى كل أحد في كل

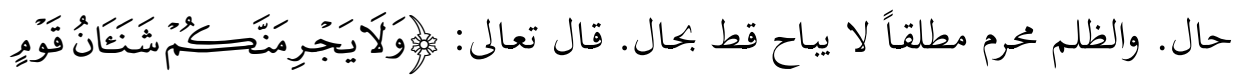

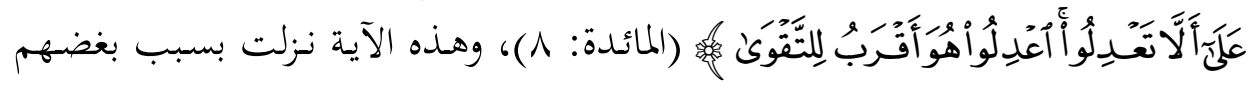

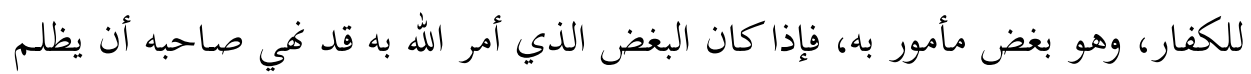

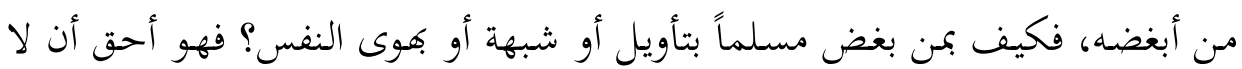

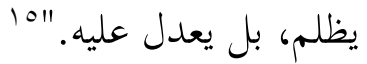
ب. السكوت عن الإنكار لا يفيد الإباحة: من أصول بيان الحقّ ونشر الخير، الرفق بعل

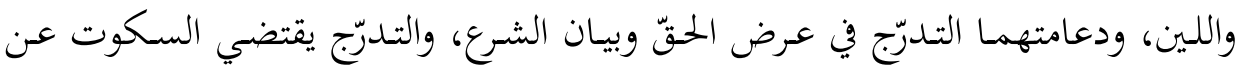

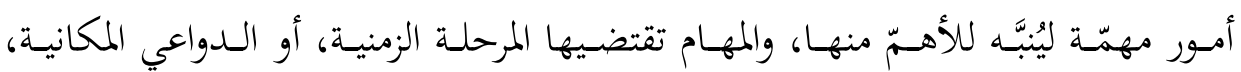

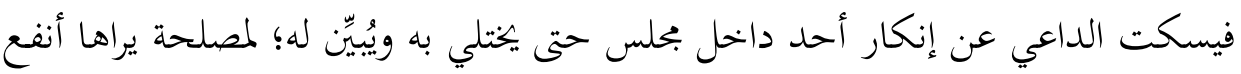

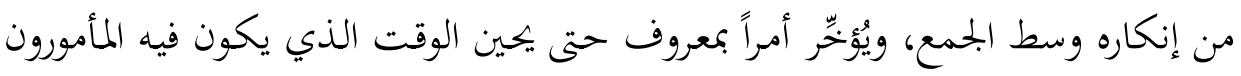
مهيّئين لقبوله، والمعارضون في ضعف ونف عن منعه.

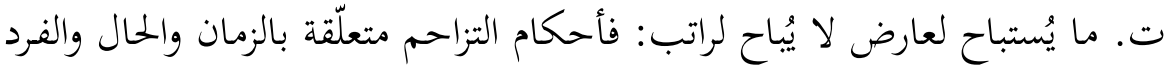

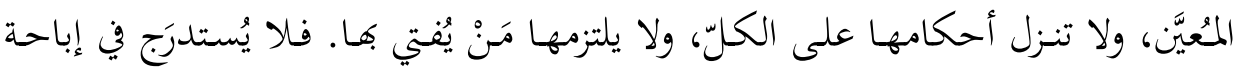

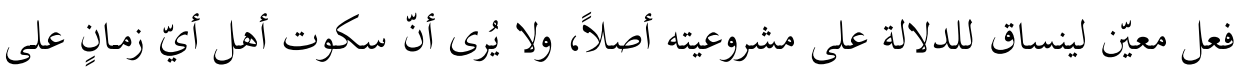

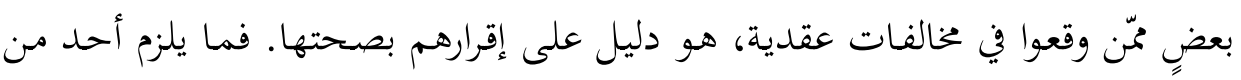

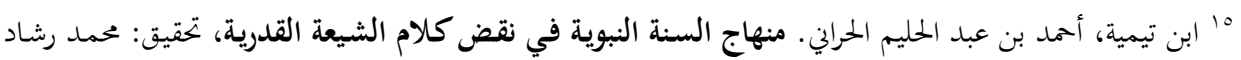

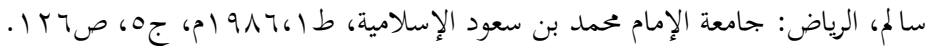


العلم والعمل قد لا يلزم غيره، وما يحاسب المؤمن عليه غير مـا يحاسب المسلم، والناس

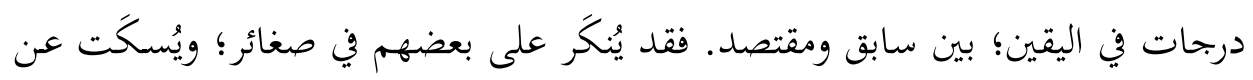
بعضٍ آخر في كبائر؛ لدواعِ عارضة طارئة.

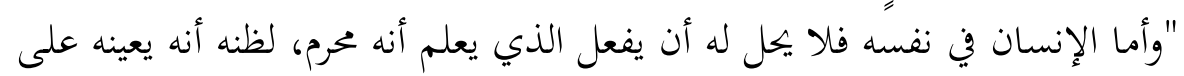

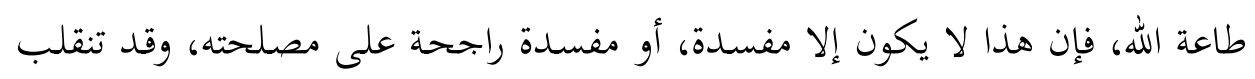

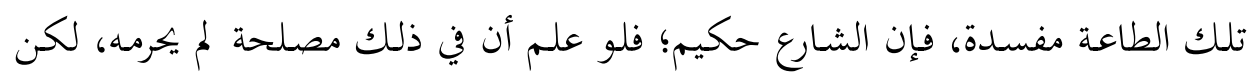

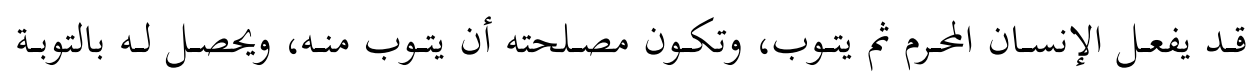

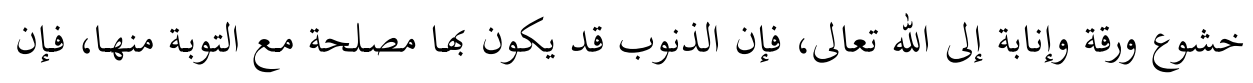

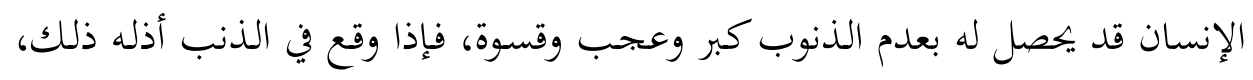

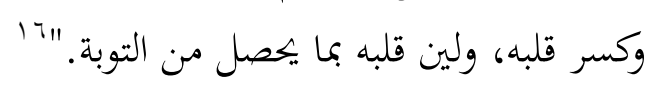

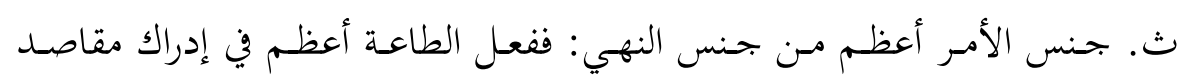
الشريعة، من ترك المعصية؛ من حيث الجنس؛ إذ الفعل أعظم من الترك من حيث القدرة،

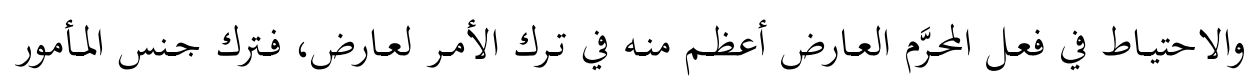

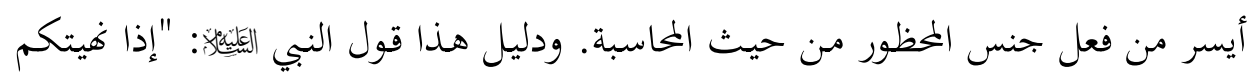

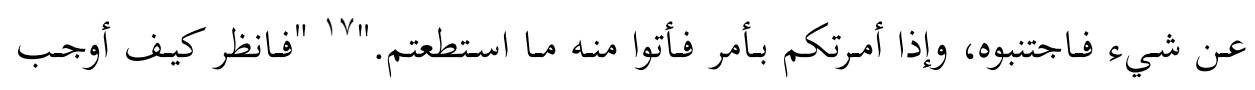

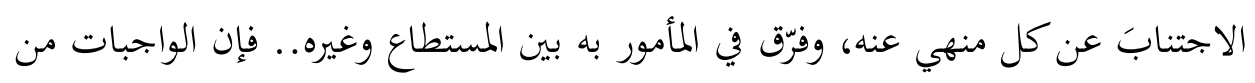

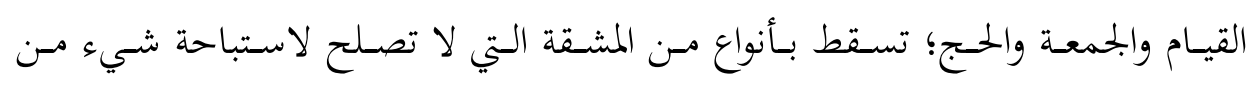

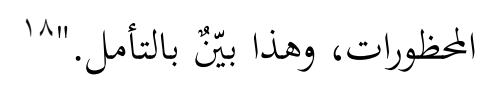

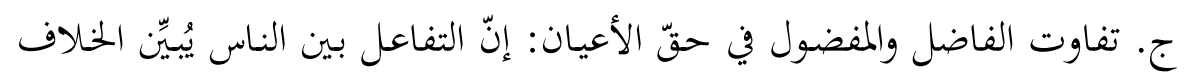

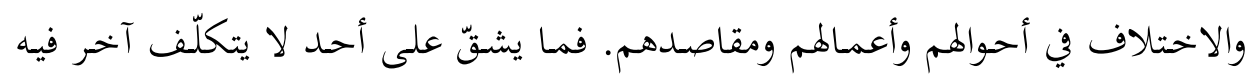
جهداً، وما يسابق له من الخيرات أفراد، قد يعجز عن وعن أقلّ منه أناس.

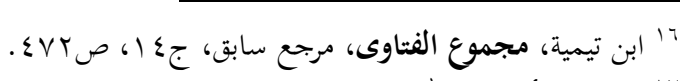

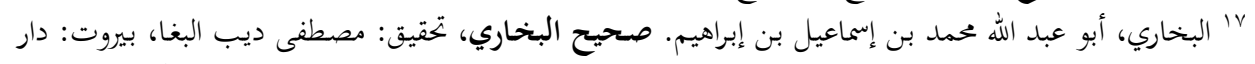

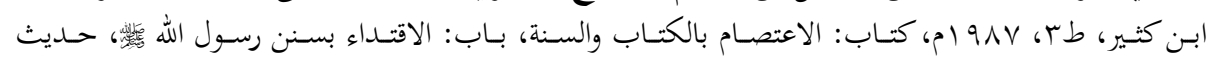

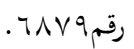

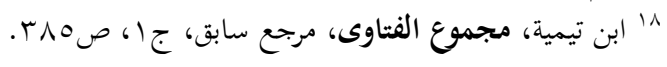


فـالمؤمنون درجـات في الإيمـان، يزيــ ويـنقص بيـهـم، ويصـعد وينـزل في حسال الفـرد

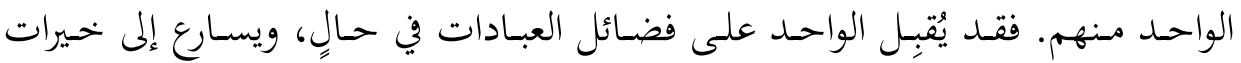

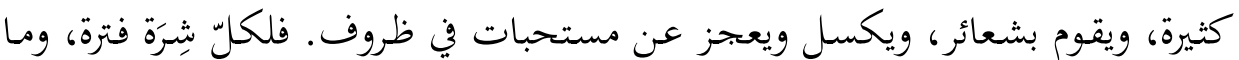
مدح في الشِرَة لا يوجب الذم على تركه في الفترة؛ إلّا أن يقبل على معلى معصية.

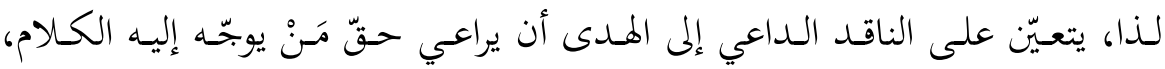

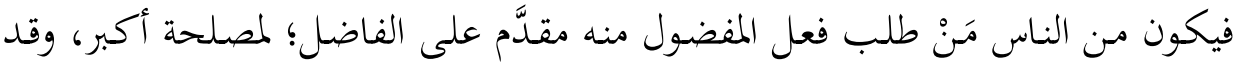

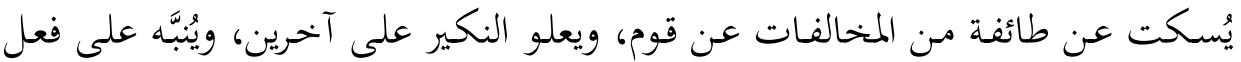

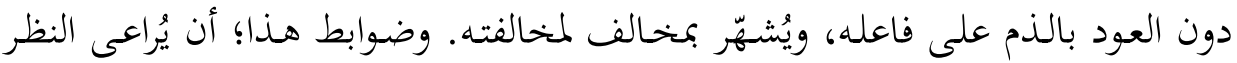

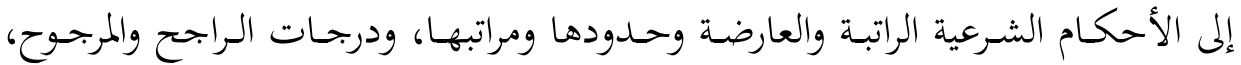

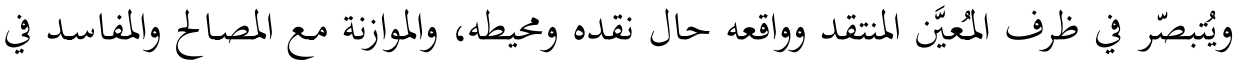

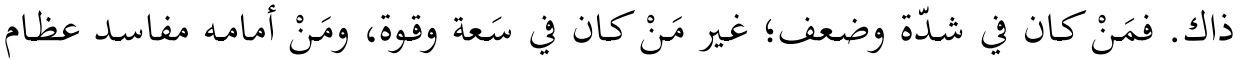
يدرؤها بجها جهيد، لا ينظر إلى ما فاته من إصلاح مفاسد أقلّ.

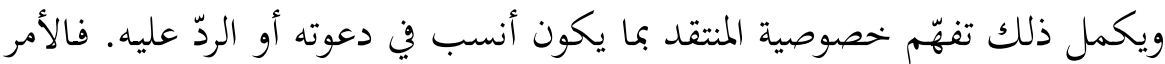

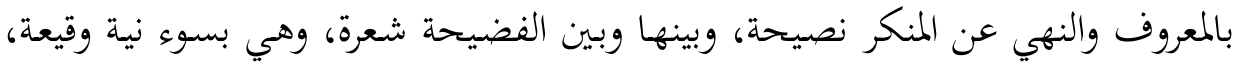

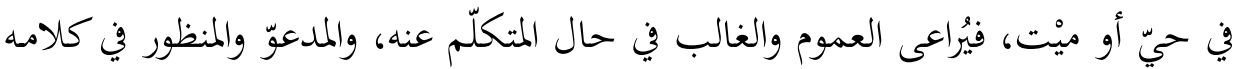

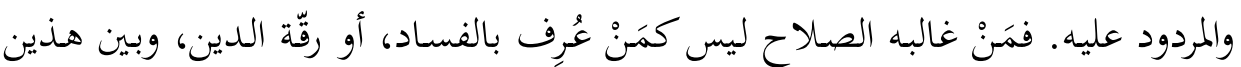
أقوام وطبقات، فيُنظَر في الفعل تيمّ فاعله.

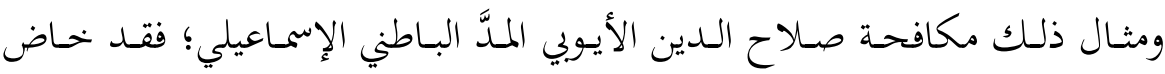

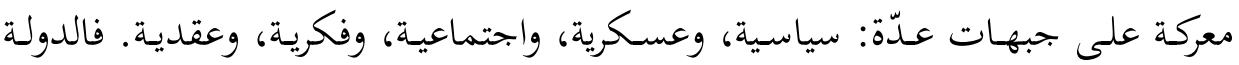

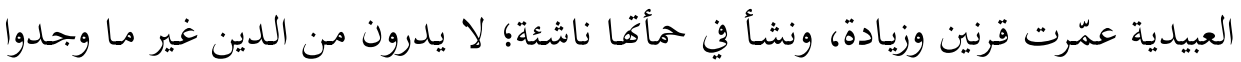

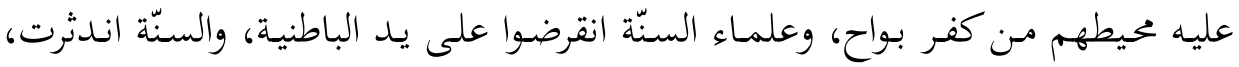

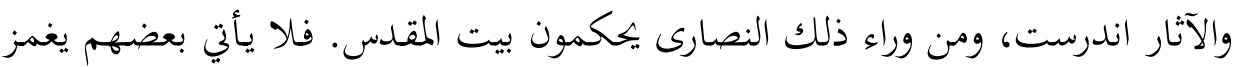

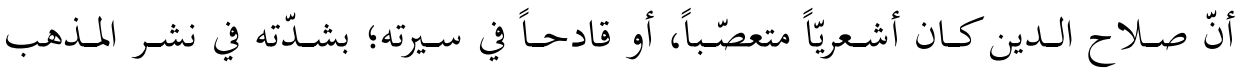

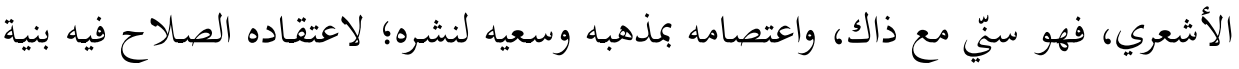

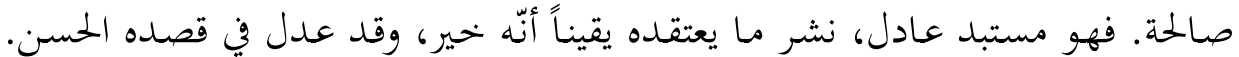

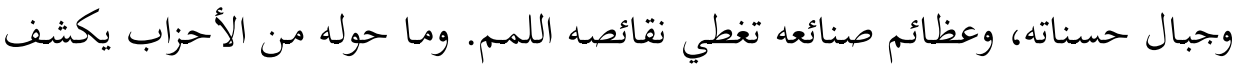




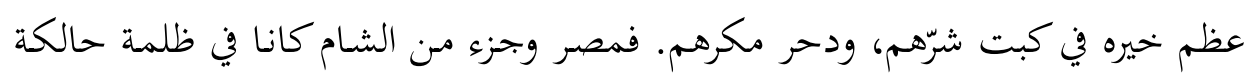

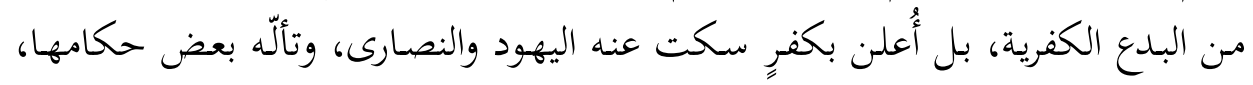

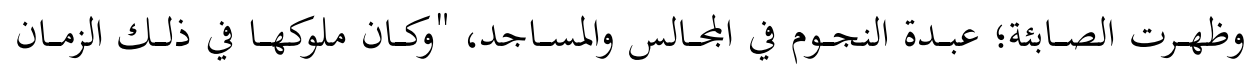

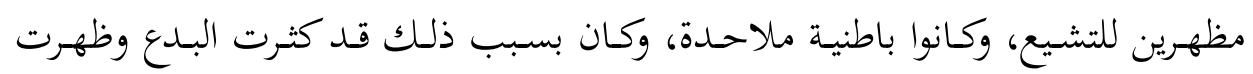

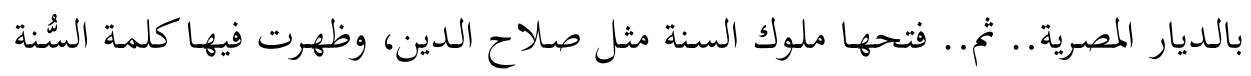

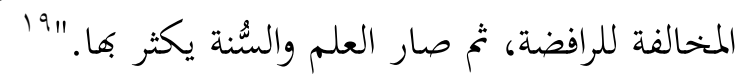

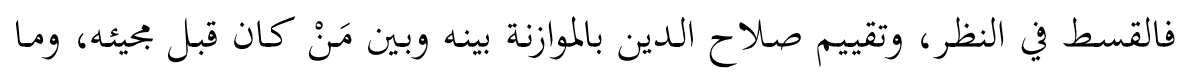

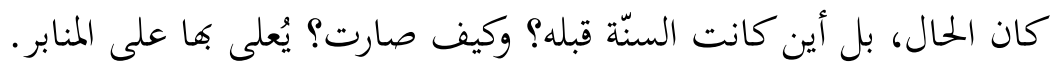

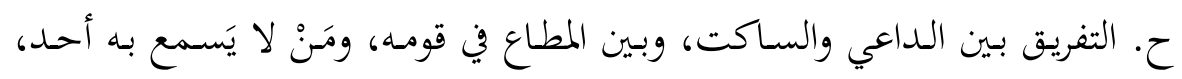

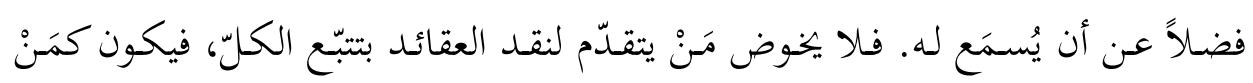

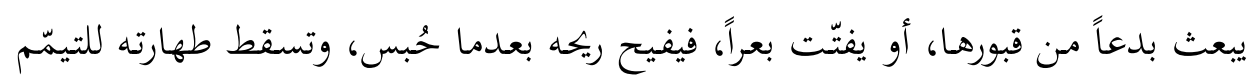

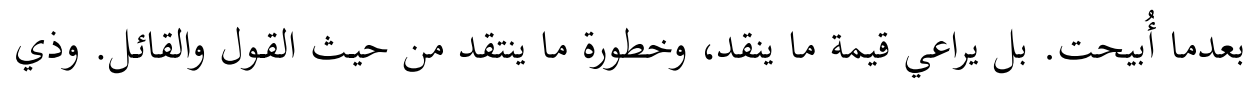

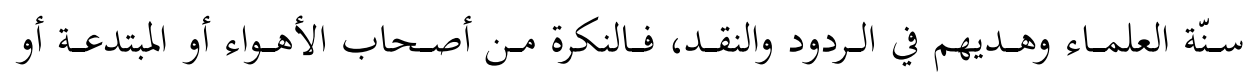

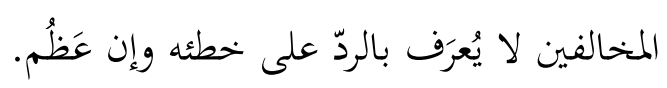

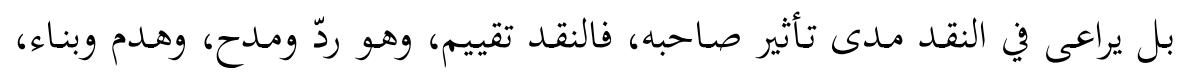

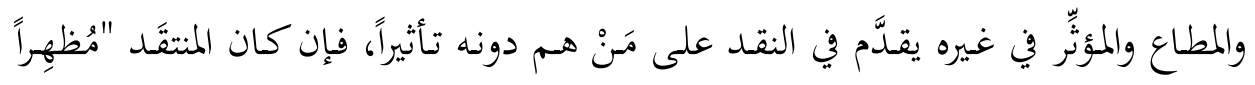

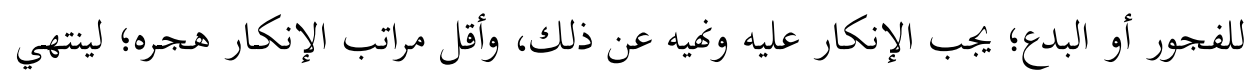

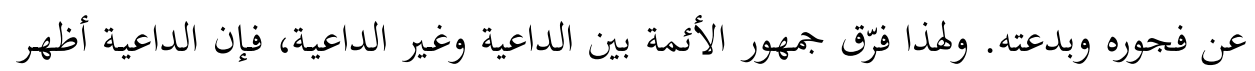

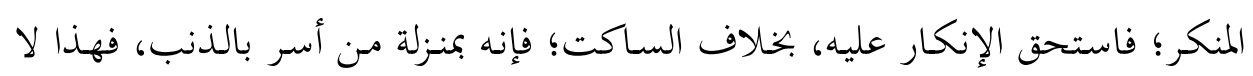

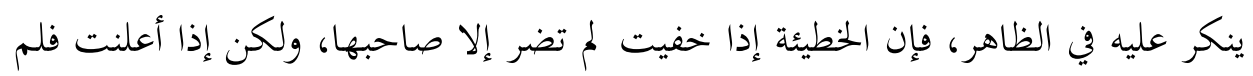

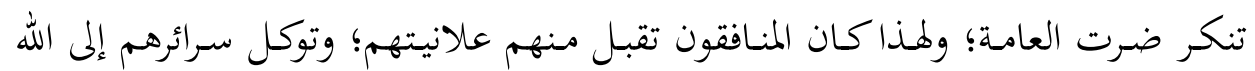

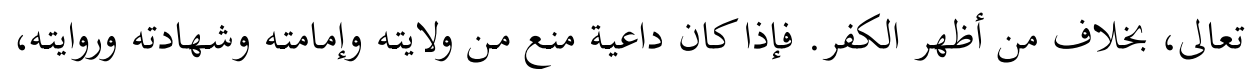

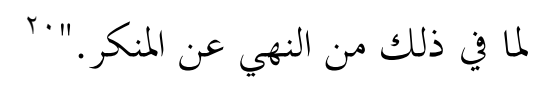

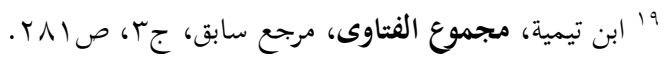

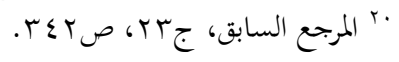




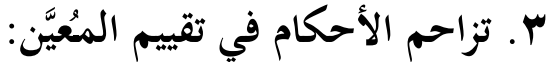

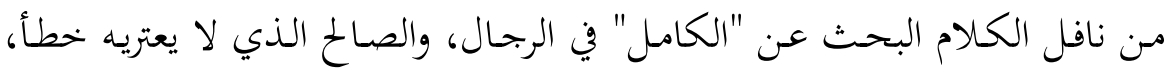

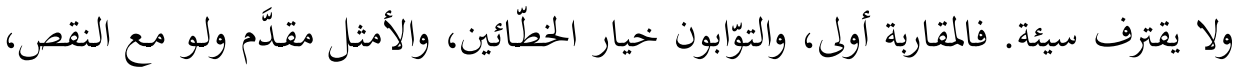

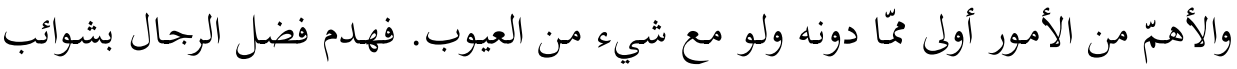

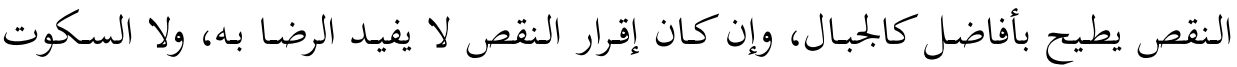

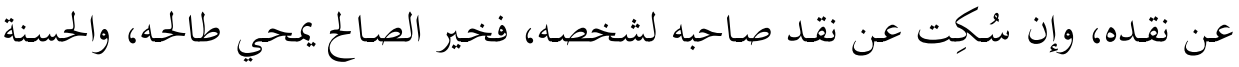

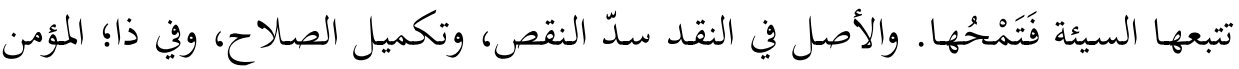

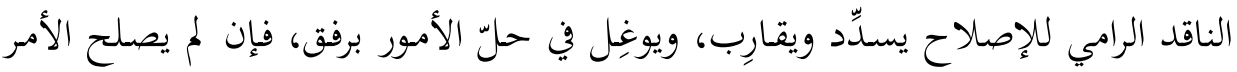

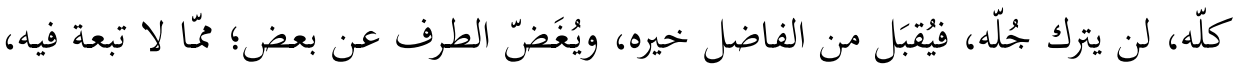
ولا يتابع به، وإن نقد الفعل لذاته.

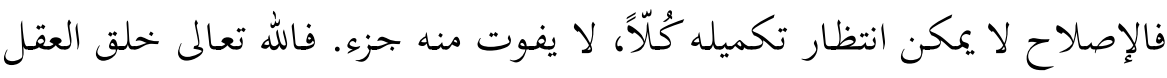

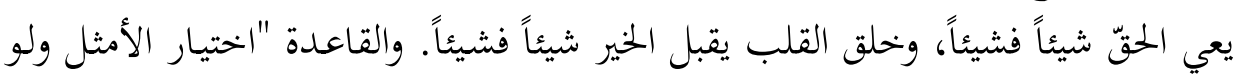

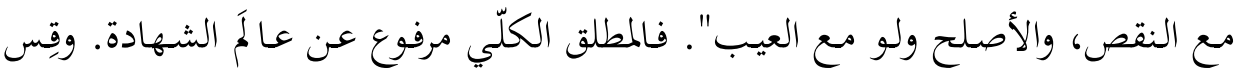

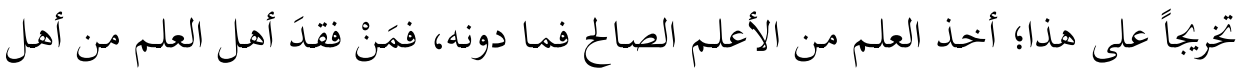

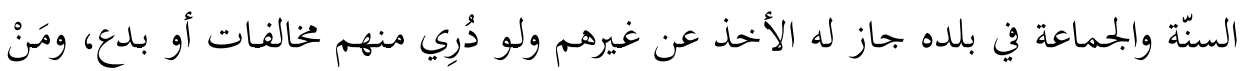

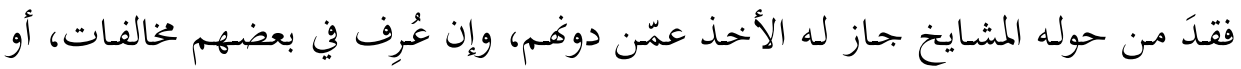

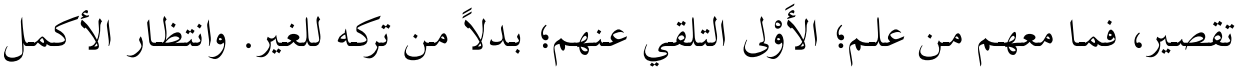

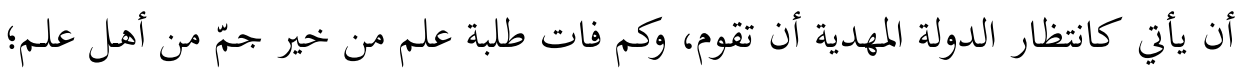

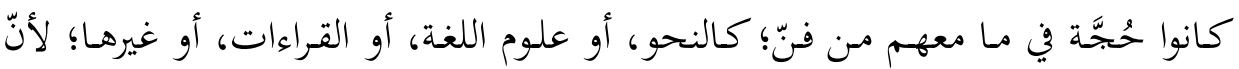

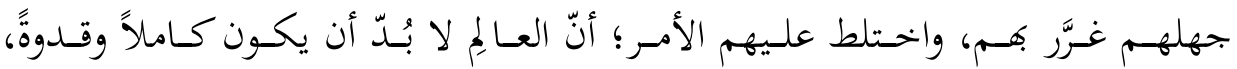

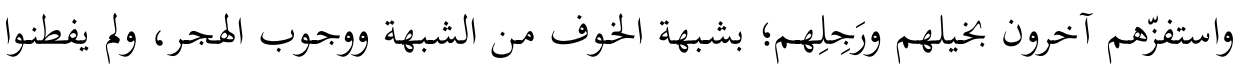

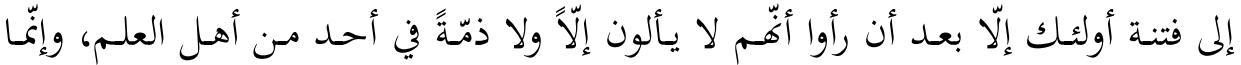

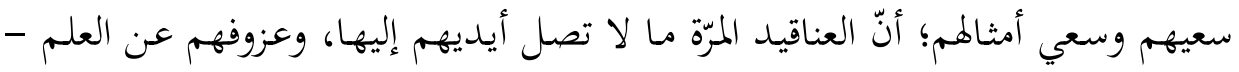

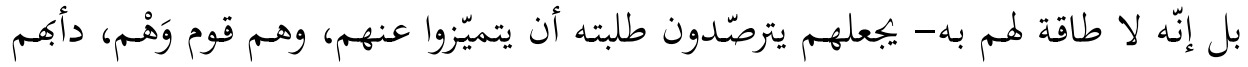

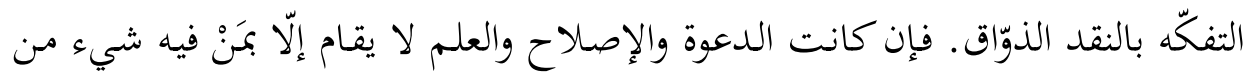




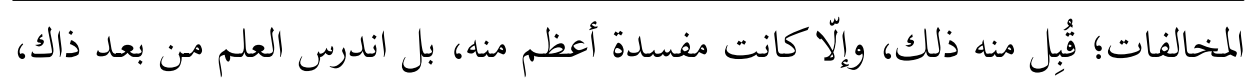

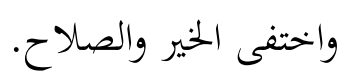

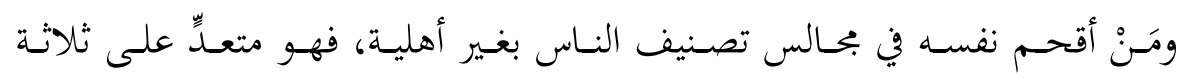

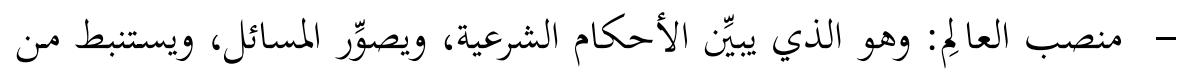

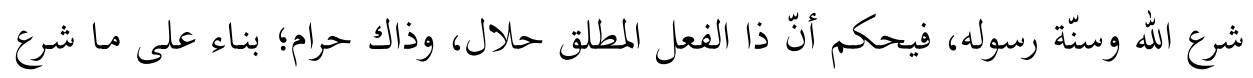
من الله ورسوله.

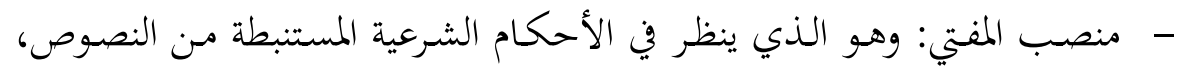

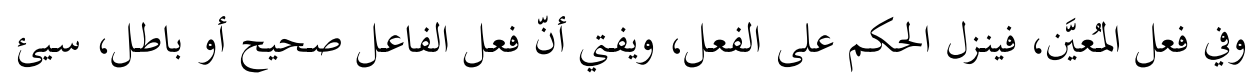
أو حسن.

- منصب القاضي: وهو الذي ينظر في حكم العالمٍ وفتوى المفتي، فينظر في الحكم

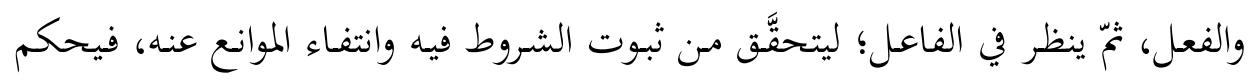

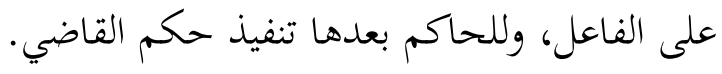

\section{ع ـ التزاحم بين إثبات الشروط والموانع}

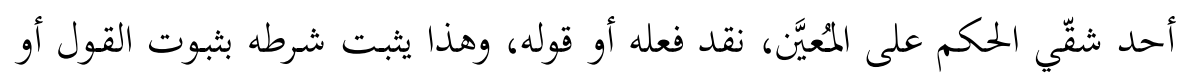

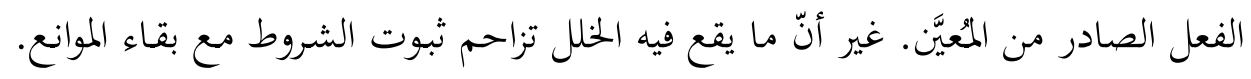

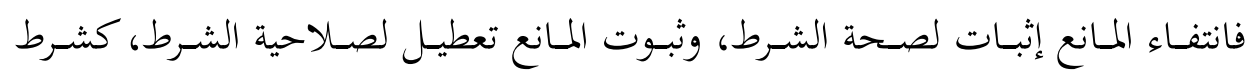
لإصدار الحكم، وهذا ضابط في غاية الأهمية.

واجتماع الشروط هنا يفرض على بعض مَنْ يتصدّى للحكمى على الأعيان اختصار

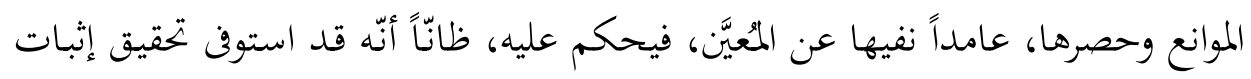

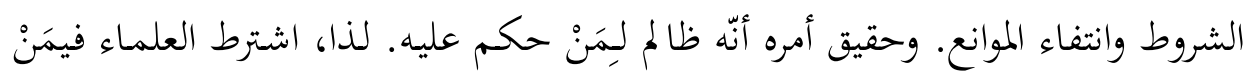

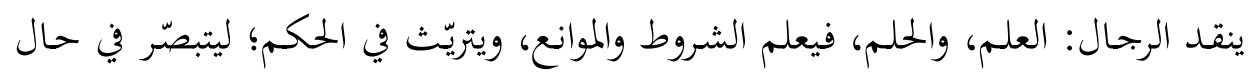

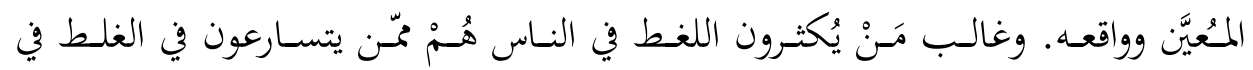
الحكم؛ بإعمال الشروط، وإهمال الموانع كلّها أو بعضها. 


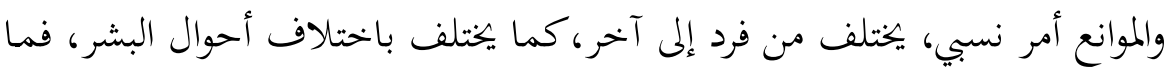

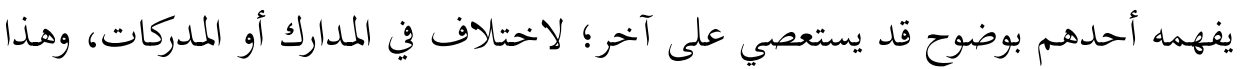

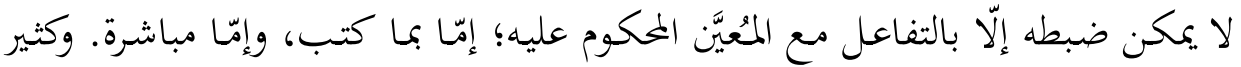

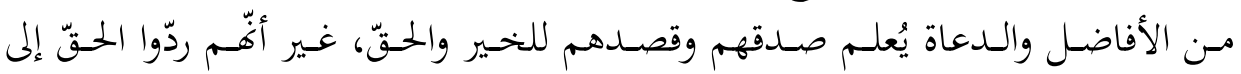

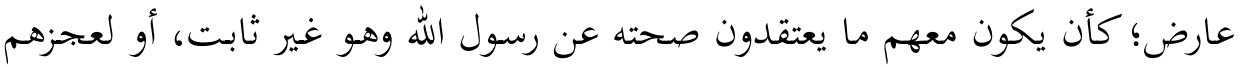

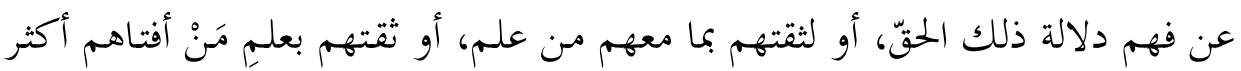

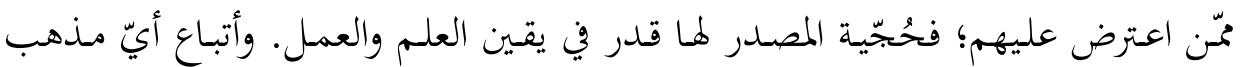

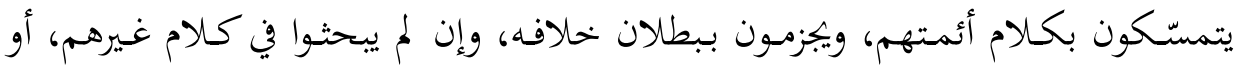

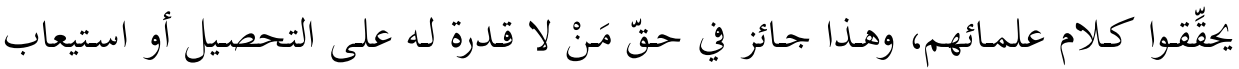

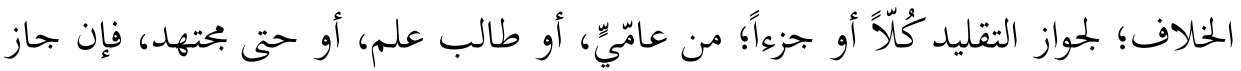

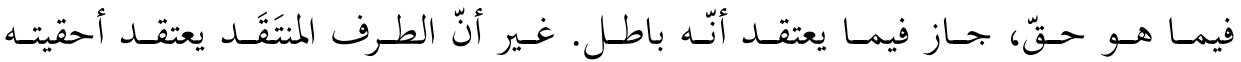

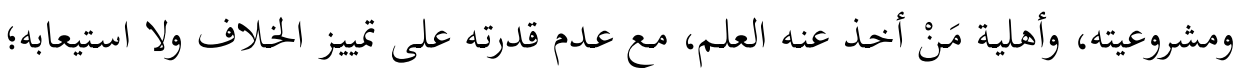

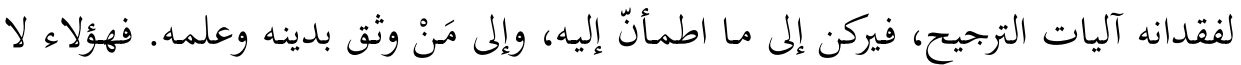

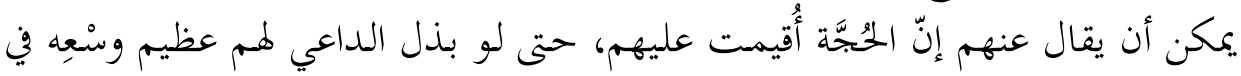

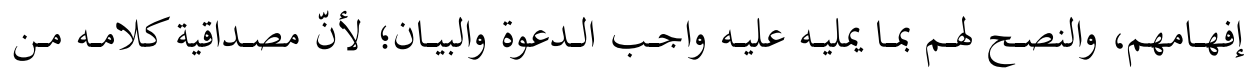

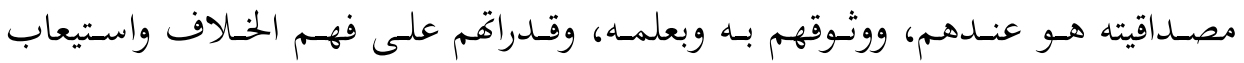

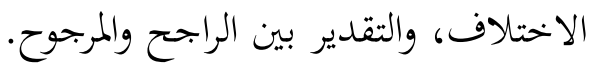

فهنا مانعان من الموانع المهمّة التي تؤثبّر في قَبول المسائل الشرعية وردّها: - الأول متعلّق بالمُعيَّن؛ إذ تتفاوت قابلية استيعابه العلومَ؛ وذلك تبعاً لفهم دلالة تلك المسائل وأدلتها، والتمييز بين الاختلاف الواقع بين هذه الدلالات بلات والأدلة. - والثاني ذو صلة بالمسألة المُعيَّنة، وهو يتمثَّل في دقّة المسائل الشرعية نفسها. فمن العلم ما هو واضح جليّ، ومنه الغامض الذي يحتاج إلى ذهن حادّ، وقريحة وقّادة، قَّلَّ مَنْ

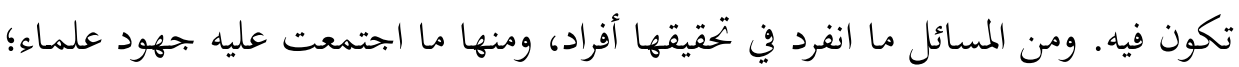

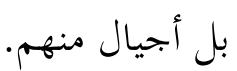

والتفـاوت الأول فطري، أمّـا الثـاني فقَدَري، فـلا لـوم على أحسد فيهمـا، واجتمـاع هذين التفاوتين سبب معتبر للاختلاف، لا سيّما في المسائل العلمية الدقيقة. 


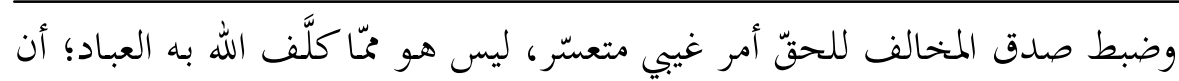

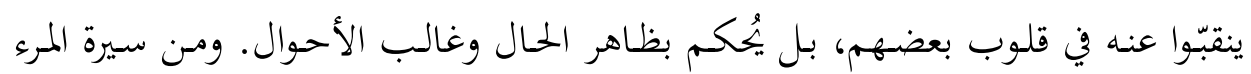

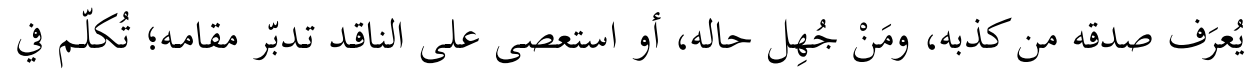

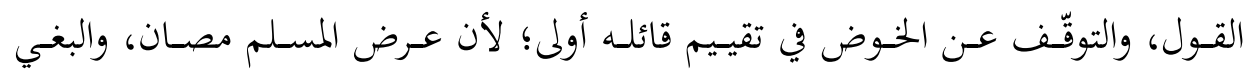
باللسان محرم.

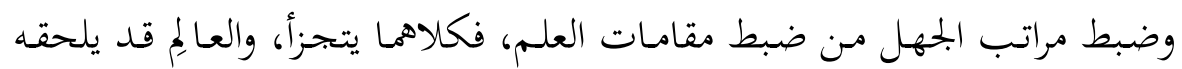

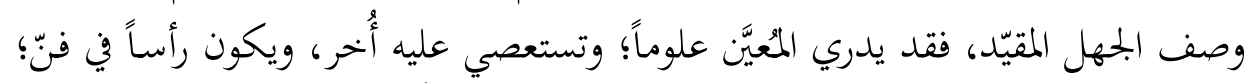

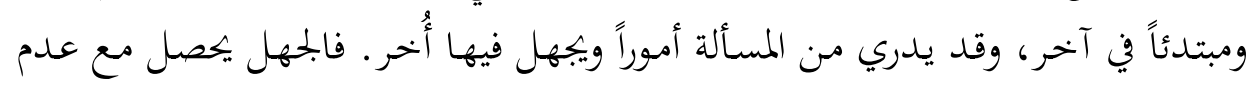

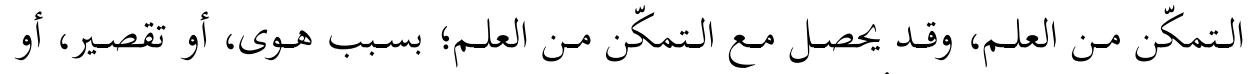

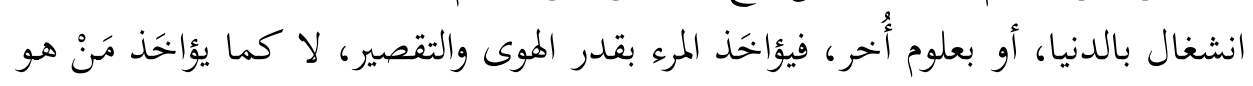

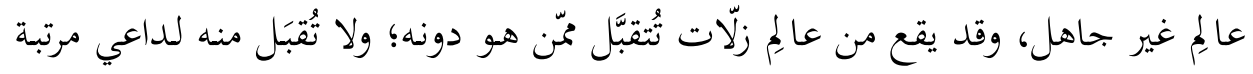

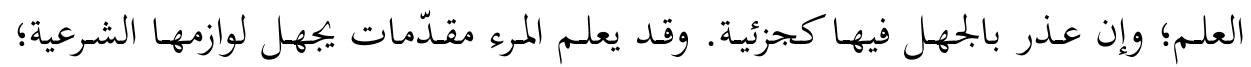

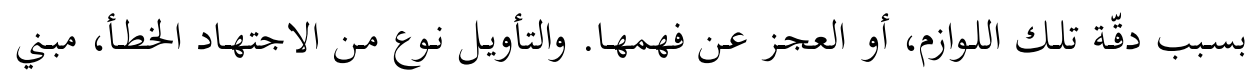

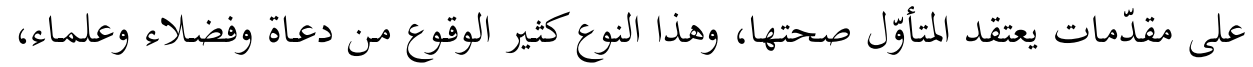
فينتبه بعضهم، ويغفل عنها آخرون.

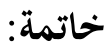

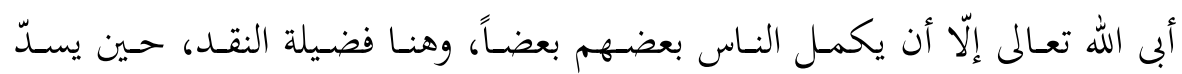

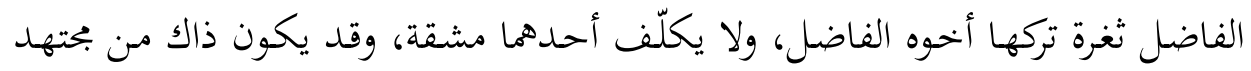

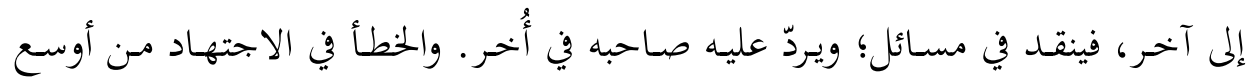

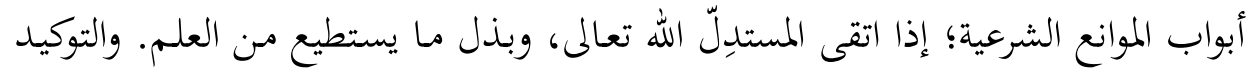

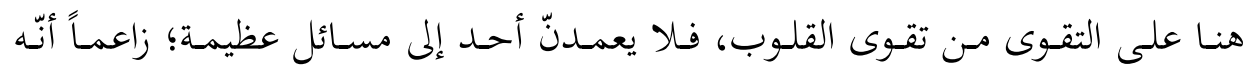

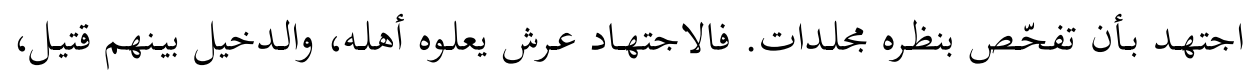

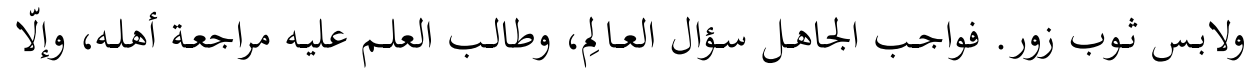
ظهر الفساد، وعمَّت الفوضى العلمية، واضطربت ساحة الفتوى. لمادئ 


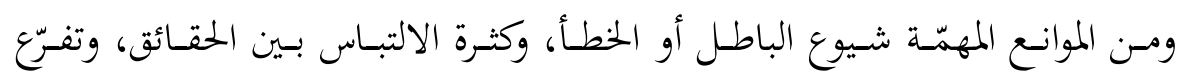

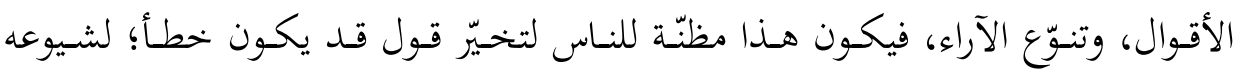

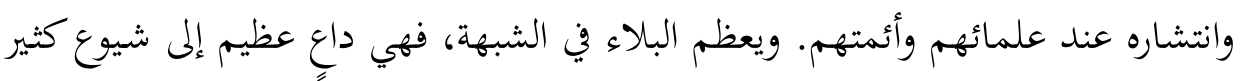

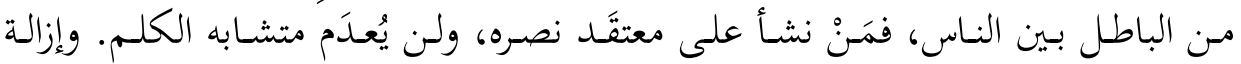

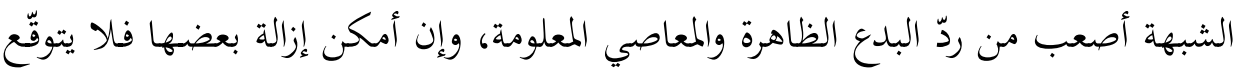

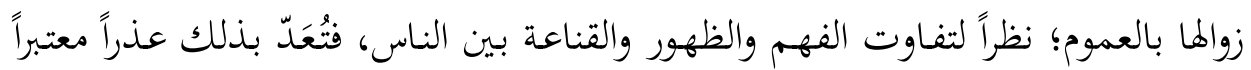

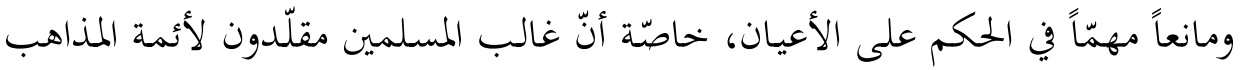
وأتباعهم. ومانعا مقاع.

فمهمّة نشر العلم الشرعي الصحيح بين المشايخ أولى، والبيان للشيخ ليس كالبيان

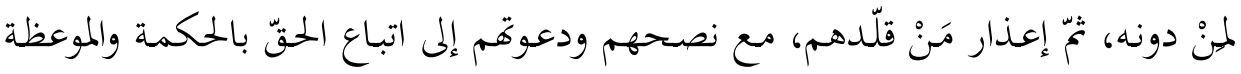
الحسنة.

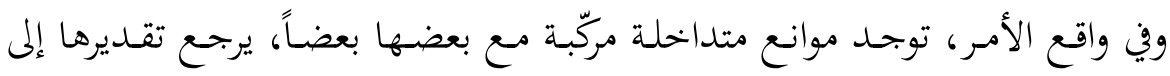

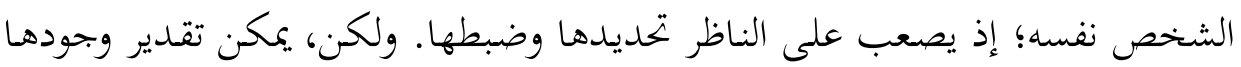

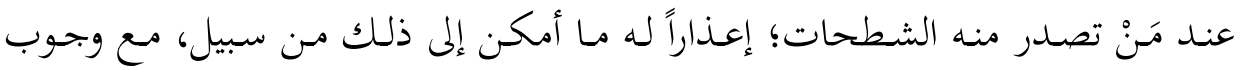

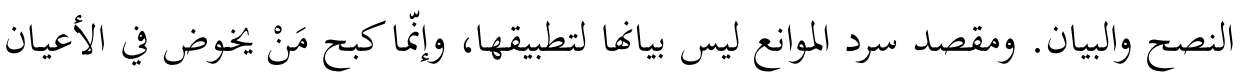

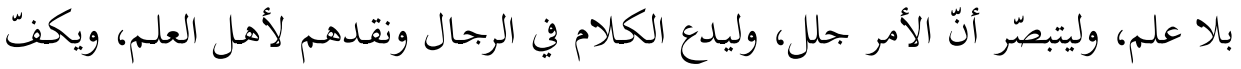

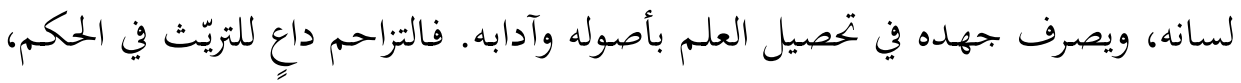
واشتراط الأهلية فيمَنْ يتصدّر لتصنيف الناس، وبيان أوجه التعامل معهِم. لأجل ذلك؛ كان من زبـدة البحث الاستفسار عن التكامل في ردّ الباطل الأعظم

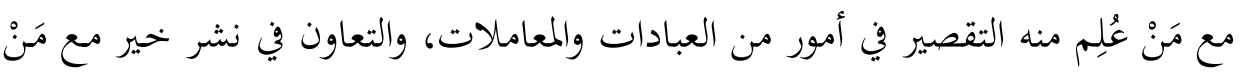

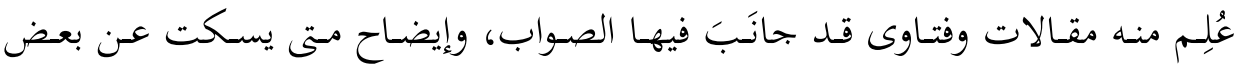

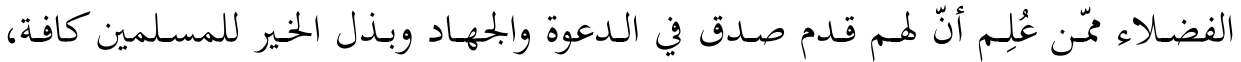
وبحـث الأسـاليب الشرعية في التنبيه على المخالفـات العقدية، أو الأخطاء الفقهية بروح علمية اجتهادية. 